\title{
Building a Better Union: Incentivizing Structural Reforms in the Euro Area
}




\title{
WP/15/201
}

\section{IMF Working Paper}

\section{Building a Better Union: Incentivizing Structural Reforms in the Euro Area}

\author{
Angana Banerji, Bergljot Barkbu, James John, Tidiane Kinda, \\ Sergejs Saksonovs, Hanni Schoelermann, Tao Wu
}

IMF Working Papers describe research in progress by the author(s) and are published to elicit comments and to encourage debate. The views expressed in IMF Working Papers are those of the author(s) and do not necessarily represent the views of the IMF, its Executive Board, or IMF management.
I N
T E R
N A T I O N A L
$M O N E T A R Y$
F U N D 


\title{
IMF Working Paper
}

European Department

\author{
Building A Better Union: Incentivizing Structural Reforms in the Euro Area \\ Prepared by Angana Banerji, Bergljot Barkbu, James John, Tidiane Kinda, \\ Sergejs Saksonovs, Hanni Schoelermann, and Tao Wu \\ Authorized for distribution by Kenneth Henry Kang
}

September 2015

\begin{abstract}
IMF Working Papers describe research in progress by the author(s) and are published to elicit comments and to encourage debate. The views expressed in IMF Working Papers are those of the author(s) and do not necessarily represent the views of the IMF, its Executive Board, or IMF management.
\end{abstract}

\begin{abstract}
The momentum for structural reforms is waning in the euro area at a time when even faster progress is needed to boost productivity and growth, achieve real economic convergence, and improve the resilience of the monetary union. What can the European Union (EU) institutions do to bridge this divide? This paper argues for greater simplicity, transparency and accountability in the EU governance framework for structural reforms. Our three interrelated proposals - "outcome-based" benchmarking; better use of existing EU processes to strengthen oversight and reduce discretion; and improved financial incentives - could help advance reforms. Ex post monitoring by an independent EU-level "structural council" and ex ante policy innovation by national productivity councils could strengthen accountability and ownership. Deeper governance reforms should be considered in the medium-term with a view toward a greater EU role in promoting convergence.
\end{abstract}

JEL Classification Numbers: P11, P16, H77

Keywords: Structural reform, European economic governance, European Union

Author's E-Mail Address: ABanerji@,imf.org, BBarkbu@,imf.org, JJohn@,imf.org, TKinda@imf.org, SSaksonovs@imf.org, HSchoelermann@imf.org, TWu@imf.org 
I. Why should the EU incentivize structural reforms in the Euro Area?

II. A Complex Framework

III. The Current Framework: How Effective?

A. EU Legislation Has Been Effective

B. EU Policy Coordination: Mixed Success

11

IV. Three Proposals to Strengthen Incentives 14

A. Proposal 1: Shifting to "Outcome-based" Benchmarks on Area-wide Priorities

B. Proposal 2: Making More Effective Use of EU Authority $\underline{23}$

C. Proposal 3: Strengthening Financial Incentives 27

V. Summary and the Way Forward: Moving to a Structural Union

Boxes

1. Financial Sanctions Within The Governance Framework $\underline{15}$

2. Structural Reforms and the SGP $\underline{28}$

Tables

1. Possible Outcome-Based Benchmarks on Area-Wide Priority Reforms $\underline{20}$

2. Examples of Outcome-Based Directives and Regulations $\underline{24}$

3. Alternative Specification of 2014 CSR Recommendations: Some Examples $\underline{26}$

4. National Productivity Councils of Australia, Belgium, Germany and New Zealand: A Brief Summary $\underline{36}$

Figures

1. Euro Area Productivity $\underline{4}$

2. EU Governance Framework for Structural Reforms - An Illustration $\underline{8}$

3. Europe 2020 Headline Indicators - Target Values and Progress Since 2008

4. Country Compliance with CSRs

5. Progress Toward 2014 CSR Targets 13

6. Three Complementary Proposals for Strengthening the Governance of Structural Reforms: An Illustration $\underline{16}$ 
7. Structural Reform Indicators: Distance to OECD Best Practice

8. Direct Fiscal Costs of Reforms 29

9. Fiscal Costs of Measures Compensating Redistributive Effects of Labor Reforms $\underline{31}$

10. European Structural and Investment Funds $\underline{33}$

References $\underline{38}$ 


\section{WHY SHOULD THE EU INCENTIVIZE STRUCTURAL REFORMS IN THE EURO AREA?}

\section{There is general consensus that structural reforms are needed to boost the euro area's}

growth potential. Although the euro area has enjoyed a cyclical recovery since late 2014, its medium-term growth potential has been declining. Labor productivity in the euro area has trailed the United States, especially in crucial sectors such as services and information technology (Figure 1, panel 1). The double-dip recession, followed by a protracted period of weak growth, led to persistently high and long-term unemployment and low private investment. These crisis legacies and growing demographic pressures on top of sluggish productivity have eroded potential output, weakening the capacity of the euro area to bootstrap strong growth.

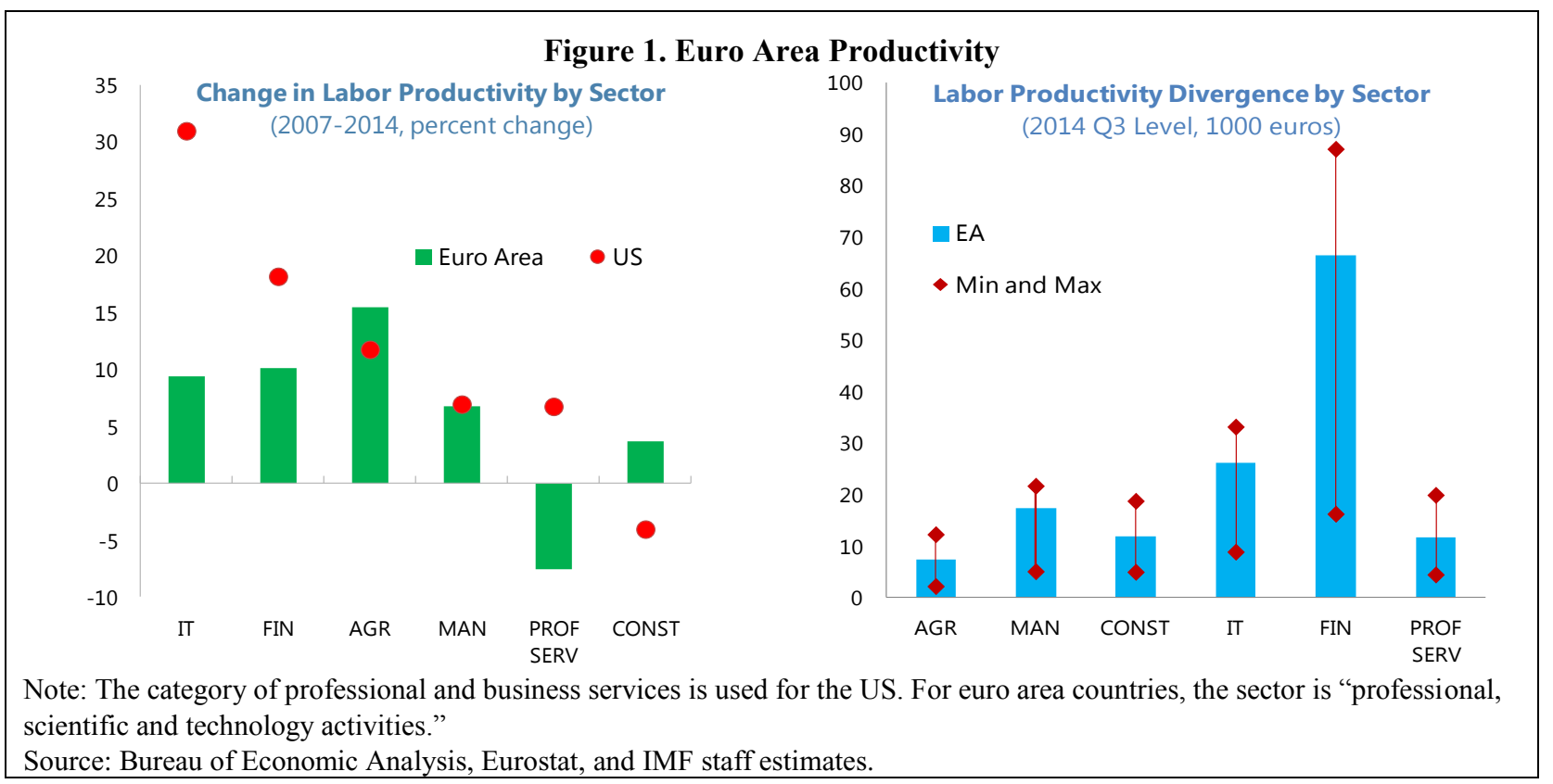

There is also a widely held view that structural reforms are necessary to reduce significant productivity gaps within the monetary union (Figure 1, panel 2). These productivity gaps, especially in the service sectors, have been attributed to lagging product market reforms (Coeuré, 2014). Sustained divergence in productivity levels within the euro area is undesirable as it could foster imbalances, thus creating adverse spillovers for all members and the monetary union (Draghi, 2014).

\footnotetext{
${ }^{1}$ We would like to thank Mahmood Pradhan, Kenneth Kang, Shekhar Aiyar, Helge Berger, Christian Mumssen, and Rishi Goyal (European Department, IMF); and, Isabel Grilo, Alessandro Turrini, Emmanuelle Maincent, and Marion Perelle (European Commission) for their thoughtful comments on earlier drafts. We are also grateful to Jesse Siminitz and Katherine Cincotta for excellent research and administrative assistance respectively.
} 


\section{Thus, continued progress on structural reforms is needed to boost growth, productivity,} and competitiveness, and further economic convergence (Juncker et al., 2015; Van Rompuy et al., 2012; Draghi, 2014). It is estimated that closing 10-20 percent of the distance to best practices in the OECD in product and labor markets could help raise euro area GDP by $3 \frac{1}{2}$ percent in 2019 compared to the baseline scenario (IMF, 2014a). ${ }^{2}$ A number of other studies reach similar conclusions, e.g., Anderson et al. (2014), Barkbu et al. (2012), ECB (2015a), Hobza and Mourre (2010), Varga and int'Veld (2013). Bouis and Duval (2011) find that there is ample room for structural reforms to offset the permanent GDP losses from the recent crisis in OECD countries with output gains close to 10 percent at the ten-year horizon.

However, the impetus for more reforms seems to be waning, especially those led by the European Union (EU) institutions. ${ }^{3}$ There is also a risk that, without a pickup in growth, reforms already implemented may be reversed. While the positive effects of structural reforms on investor confidence, medium-term growth potential and productivity are generally not questioned, reforms are perceived to have short-term economic and political costs. And, in a vicious circle, the lack of popular support for reforms is due, in part, to the failure to implement comprehensive measures, which has diluted the benefits of the reforms that were implemented and led to perceptions of unfairness (Coeuré, 2014). Moreover, there is a widespread view that market pressures are a primary motivator for structural reforms including in the euro area ${ }^{4}$. There is therefore a concern that better financial market conditions could make the need for structural measures seem less urgent. ${ }^{5}$

\footnotetext{
${ }^{2}$ Estimates are derived using the IMF's EUROMOD multi-economy model.

${ }^{3}$ For the purposes of this paper, EU institutions refer to the European Commission (EC), the Council of the European Union (Council), and the European Parliament (Parliament).

${ }^{4}$ See for example, Lora and Olivera (2004) for Latin America, Allard et al., (2010) for the euro area and Agnello et. al. (2015) for OECD countries. Empirical research generally supports the role of market pressure in motivating reforms in a large number of countries and across a broad category of reforms, although the results are less convincing for labor market reforms.

${ }^{5}$ These developments are consistent with the general findings of the literature on why structural reforms are difficult to implement. The explanations advanced in this line of research highlight the resistance to reforms if the public is uncertain over the precise benefits of structural reforms as well as if vested interests are affected. Second, it may be difficult to reform institutions that were originally introduced with the aim of playing an important social role in mitigating market failures. Third, structural reforms may have significant redistributive effects leading to political economy considerations in how far to push for reforms. See Leiner-Killinger et. al. (2007) for an overview of the literature on factors affecting structural reform implementation.
} 


\section{The EU's role in incentivizing reforms arises from the gap between the need and the will}

for structural reforms. The EU is best positioned to consider whether individual euro area member states are sufficiently flexible and resilient to economic shocks to make the overall monetary union function well. This is particularly important in the absence of a political union to foster cohesion and facilitate fiscal transfers between richer and poorer regions. And it is the EU that is charged with helping ensure sustained real convergence among euro area member states. Thus, there is growing recognition that the European framework governing reforms needs to be able to ensure that there is continued progress in the current economic and political environment. ${ }^{6}$ The 2012 Four Presidents' Report (Van Rompuy et al., 2012) highlighted the need for changes but was only partially implemented. The recent Five Presidents' report (Juncker et. al, 2015) lays out a renewed, ambitious vision for the economic governance of the European Economic and Monetary Union (EMU) with a focus on the need to promote real convergence.

\section{This paper builds on these ideas for improving structural reform governance and outlines} concrete proposals for incentivizing the implementation of reforms in the near term and over the longer haul. Throughout this paper the term "structural reforms" refers to policies across a broad range of economic areas which may be affected by the economic governance framework and the proposals in this paper. The discussion of structural reform policy priorities have been intentionally kept at a high level of generality. Instead, the paper focuses heavily on improvements to the governance framework itself, leaving discussions and prioritization of different types of structural reform policies for future work. Thus, section II takes stock of the structural reform provisions of the current EU economic governance framework. Section III describes the effectiveness of the existing modalities for incentivizing and furthering structural reform objectives in the EU-policy coordination, SGP flexibility, fiscal transfers and financial penalties, and legislative options. Section IV suggests ways in which these mechanisms might be improved in the near term. Beyond the near term, more fundamental governance changes would be helpful to ensure reforms in areas currently outside the EU's jurisdiction as well as greater convergence within the monetary union (Section V).

\footnotetext{
${ }^{6}$ See also Padoa-Schioppa et al., 2012. Ioannou and Stracca (2014) point to the need for EU economic governance reforms based on strong and robust evidence that neither the Stability and Growth Pact nor the Lisbon Strategy have had a significant beneficial impact on fiscal and economic performance.
} 


\section{A COMPlex Framework}

The European Semester "has significantly strengthened the coordination of economic policies." However, 'the addition of numerous 'packs', 'pacts', 'procedures' and manifold reporting requirements has blurred its rationale and effectiveness." Five Presidents' Report (Juncker et al., 2015).

\section{EU institutions have a limited mandate to enforce structural reforms in member states}

(Figure 2). The modalities and scope for designing and implementing structural reforms in the EU that are enshrined in the Treaty on the Functioning of the European Union (Treaty) are less specific than those for fiscal governance. This leaves scope for interpretation in the application of the rules, with fewer and weaker enforcement tools over structural reforms at the disposal of the EC and the Council.

The Treaty limits the EU's jurisdiction to areas of "exclusive" competence and "shared" competence with member states (Articles 3-6). In addition, the EU is empowered to enforce coordination mechanisms by adopting guidelines or arrangements within which member states are mandated to coordinate economic, employment and social policies; and it can guide, coordinate and supplement member state actions in certain areas (see Figure 2 for specifics).

\section{The EU governance framework consists of a range of processes and implementation tools} (also Figure 2). These tools, in principle, apply to all EU countries. ${ }^{7}$

- EU secondary legislation, comprising Regulations, Directives, and Decisions which set common standards. Regulations are directly enforceable in their entirety and imply a unification of rules, whereas Directives aim at harmonization and are used to bring national laws in line with a specified objective, leaving national authorities some discretion over the speed and process by which to achieve Directives' goals.

\footnotetext{
${ }^{7}$ There are some exceptions, e.g., non-euro area countries cannot be sanctioned under the MIP, and the MIP framework does not apply to countries receiving support under financial assistance programs.
} 
Figure 2. EU Governance Framework for Structural Reforms-An Illustration

EU Authority Member State Jurisdiction EU Enforcement and Coordination Tools

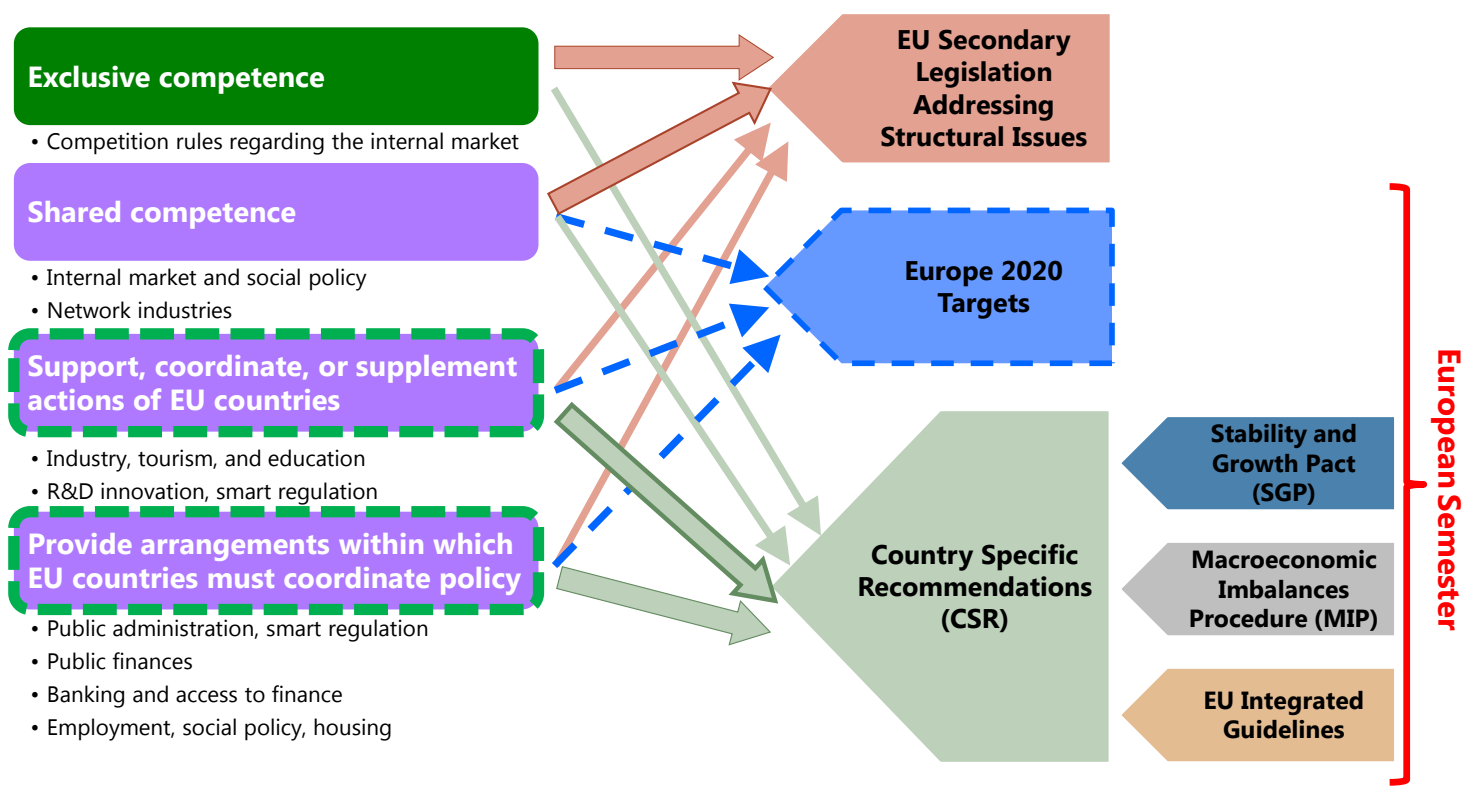

Note: Bullet points indicate areas of competence. Thickness of arrows indicates the tools most likely to be used for specific "competencies." Dashed arrows indicate that Europe 2020 targets play a relatively limited role.

Sources: European Union, IMF staff compilation.

- Economic policy coordination under the European Semester. Since 2011, EU countries coordinate fiscal, macroeconomic and structural reform policies through a common annual surveillance cycle - the European Semester — on the basis of national reform and stability or convergence programs. This coordination is based on Articles 121 and 148 of the Treaty (on economic policy coordination and employment policies) and in conformity with the Integrated Guidelines. Coordination was strengthened by the Six-pack and Two-pack legislation, which increased the EU's capacity to enforce reforms in euro area countries through financial sanctions under certain circumstances.

i. Country-Specific Recommendations (CSRs). Each year, during the European Semester, the EC assesses economic developments, including progress toward Europe 2020 targets, ${ }^{8}$ and proposes CSRs in a wide range of areas including product markets, R\&D

\footnotetext{
${ }^{8}$ One of the objectives of the new governance framework is to further the goals of the Europe 2020 strategy which replaced the Lisbon Agenda in 2010. The targets under the Europe 2020 strategy are: (i) 75 percent employment rate among 20-64 year olds, (ii) 3 percent of EU GDP investment in R\&D, (iii) goals on energy sustainability, (iv) reducing the rate of early school leaving below 10 percent and ensuring at least 40 percent of 30-34 year olds complete third level education, and (v) at least 20 million
}

(continued...) 
and innovation, employment and social policies, public administration and finances, and the financial sector. CSRs for EU countries and the euro area as a whole are discussed and recommended by the Council to member states, adding an element of peer pressure to the EC's public opinion.

ii. Macroeconomic Imbalance Procedure (MIP). The MIP seeks to reduce macroeconomic imbalances. Under its preventive arm, the EC takes macroeconomic imbalances into account when formulating CSRs. Countries found to have severe imbalances can be put under the corrective arm — the Excessive Imbalance Procedure (EIP)—which requires submission of a corrective action plan (CAP) with a clear roadmap and deadlines for implementing structural reforms. ${ }^{9}$ For euro area countries, failure to deliver a sufficient CAP or comply with commitments can lead to financial sanctions of up to 0.1 percent of GDP per year.

- Stability and Growth Pact (SGP). The fiscal framework explicitly recognizes the role of structural reforms in achieving a sound budgetary position, and the EU can incentivize the implementation of structural reforms via its fiscal governance role.

\section{In addition to the above framework involving $E U$ institutions, reforms can also progress} via "enhanced cooperation" which allows a subset of EU countries to strengthen cooperation by adopting common legislation that does not apply to the other EU countries. This method can only be used when at least nine countries want to integrate further and no compromise can be found for the legislative initiative among all EU countries (e.g., on the financial transaction tax). It only applies to policy areas in which the EU does not have exclusive competence, and the adopted legislation must be in line with Treaty objectives and other EU law.

Taken together, the economic governance framework is quite complex, despite having been strengthened significantly compared to the pre-crisis period (European Commission, 2014a). The complexity arises due to the range of enforcement tools and overlapping processes (Figure 2). Moreover, the interaction with the SGP — a separate but overlapping framework that

fewer people in or at risk of poverty and social exclusion. The Europe 2020 targets have been further translated into national targets for member states to achieve.

${ }^{9}$ The EIP entails recommendations and decisions that are different from the MIP preventive arm, and more frequent monitoring and assessment. It remains to be seen how an EIP would be aligned with the standard EU Semester. 
has become increasingly complicated with the Six-pack and Two-pack legislation — has added to the complexity of the overall process, as has the introduction of coordination and rules-based frameworks via intergovernmental processes (e.g., the "Euro Plus Pact" and "Fiscal Compact").

\section{The Current Framework: How Effective?}

The complexity of the framework has blunted its overall effectiveness (Juncker et al., 2015). It has created communication challenges about the rationale for reforms and the role of the EU in that regard, and diluted both accountability and the ownership of reforms. It has also created perceptions of an overly intrusive EU and the lack of a level playing field. However, some aspects of the framework have worked better than others.

\section{A. EU Legislation Has Been Effective}

\section{EU legislation is a potent enforcement mechanism for reforms, but the $\mathrm{EU}$ can only} legislate in certain areas, namely where it has "exclusive" or "shared" competencies or provides arrangements for coordination (Figure 2). It cannot adopt legally binding legislation in areas - such as economic policy — where the EU's powers are restricted to providing guidelines for coordination, unless considered strictly necessary to support the functioning of the Single Market (e.g., labor mobility and pension portability). In case of non-compliance, enforcement works through infringement procedures, with an eventual imposition of fines upon non-compliant member states.

\section{Legislated reforms are implemented and legislation has generally been quite effective in} enforcing desired outcomes. More than 99 percent of Internal Market Directives have been transposed into national law (European Commission, 2014b). And upwards of 85 percent of infringement cases are typically settled due to corrective actions taken before they reach the European Court of Justice. Progress toward Europe 2020 goals may also suggest better compliance under the legislative approach (Figure 3): more progress has been made in areas where the targets are legally binding and specified in Directives (energy, climate). In contrast, there has been less progress in areas where targets are not legally binding (employment, 
poverty). Of course, the crisis contributed to both positive outcomes on energy and negative outcomes on employment.

\section{But legislation is no silver bullet. A} prominent example of legislation that has been implemented but fallen short of desired outcomes is the Services

Directive. Despite full transposition into national law by 2012, the Directive is constrained in promoting cross-border trade in services and labor mobility in part because persisting legal and administrative barriers to the Single Market limit the portability of welfare rights and access to regulated professions. ${ }^{10}$

\section{B. EU Policy Coordination: Mixed Success}

It is still early to evaluate fully the relatively new framework. This is, in part, because the MIP has not been put to the test as the smaller "imbalanced" euro area economies have been outside its scope until their recent graduation from financial programs. In addition, market pressure has also played a role in incentivizing reforms, making it difficult to disentangle which forces have driven policy changes.

\section{Nevertheless, the European Commission (2014a) notes that progress on reforms has been} stronger than under the Lisbon process and that the European Semester is an improvement over earlier surveillance of structural reforms via the so-called Lisbon process. The peer review embedded in discussions of CSRs has strengthened debate about country-specific and common policy challenges and responses among EU members (European Commission, 2014a and c).

There have also been notable successes. In line with their CSRs, Italy and Spain took measures to improve SME access to finance in 2014. While some CSR measures that were

\footnotetext{
${ }^{10}$ Low labor mobility within the EU can be linked to language and cultural differences, as well as to largely heterogeneous policy contexts, notably concerning the labor market, fiscal and social welfare policies (Alfonso et al., 2014).
} 
implemented may have been low-hanging fruit and already part of government plans, it is possible that, absent policy coordination, reforms would have been weaker (although the counterfactual is hard to establish). More generally, policy coordination has been an important mechanism to encourage action, including in larger countries, which potentially fosters solidarity and evenhandedness.

Still, progress on reforms has been slow. The EC's own assessment is that despite important progress in urgent areas after the crisis, ${ }^{11}$ compliance with CSR recommendations has been insufficient in light of the remaining reform challenges (Figures 4-5). It estimates that, for 2012 and 2013, only around 10 percent of all CSRs have been fully or largely implemented, although there has been "substantial or some progress" on more than half of the CSRs (Deroose and Griesse, 2014). Averaging across the EC's qualitative evaluations of compliance indicates that compliance with CSRs also seems to have fallen in 2014 compared to 2013 (Figure 4).

\section{A number of factors could help explain why}

\section{the current framework has not had more}

traction. Among member states, the perceived

political costs of structural reforms and opposition from vested interests (Coeuré,

Figure 4. Country Compliance with CSRs (Index, Full Compliance $=4$ )

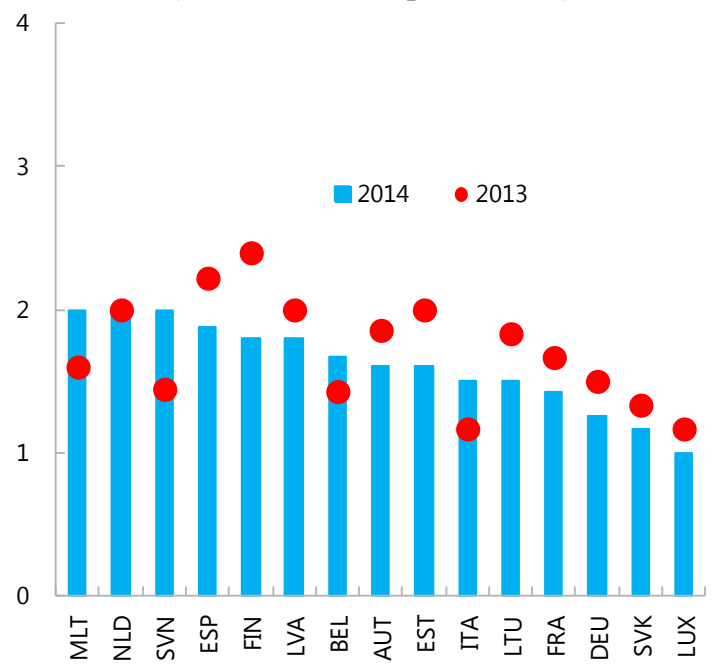

Note: The EC assesses progress on CSRs on the scale: none (0), limited (1), some (2), substantial (3), full (4). "Limited" progress indicates that some measures have been announced, but they are insufficient and/or their implementation is at risk;"some" progress denotes that measures have been announced, and are promising, but implementation is uncertain.

Source: European Commission European Semester staff working documents for years $\underline{2013}$ and $\underline{2014}$. Also in Deroose and Griesse, 2014.

2014), reform fatigue in some countries, and the lack of national ownership of reforms (Juncker et al. 2015) are often considered impediments. The lack of appetite for more integration among member states is also a factor; Juncker et al. 2015

\footnotetext{
${ }^{11}$ According to the EC, there has been significant progress in financial sector, insolvency, and pension reforms where there was greatest need after the crisis, but less progress in service sector and some product market reforms. This paper does not evaluate the strength of the reforms envisaged in the CSRs other than to note that there is some overlap between the priority measures proposed by the IMF, EC and the OECD in various policy areas.
} 


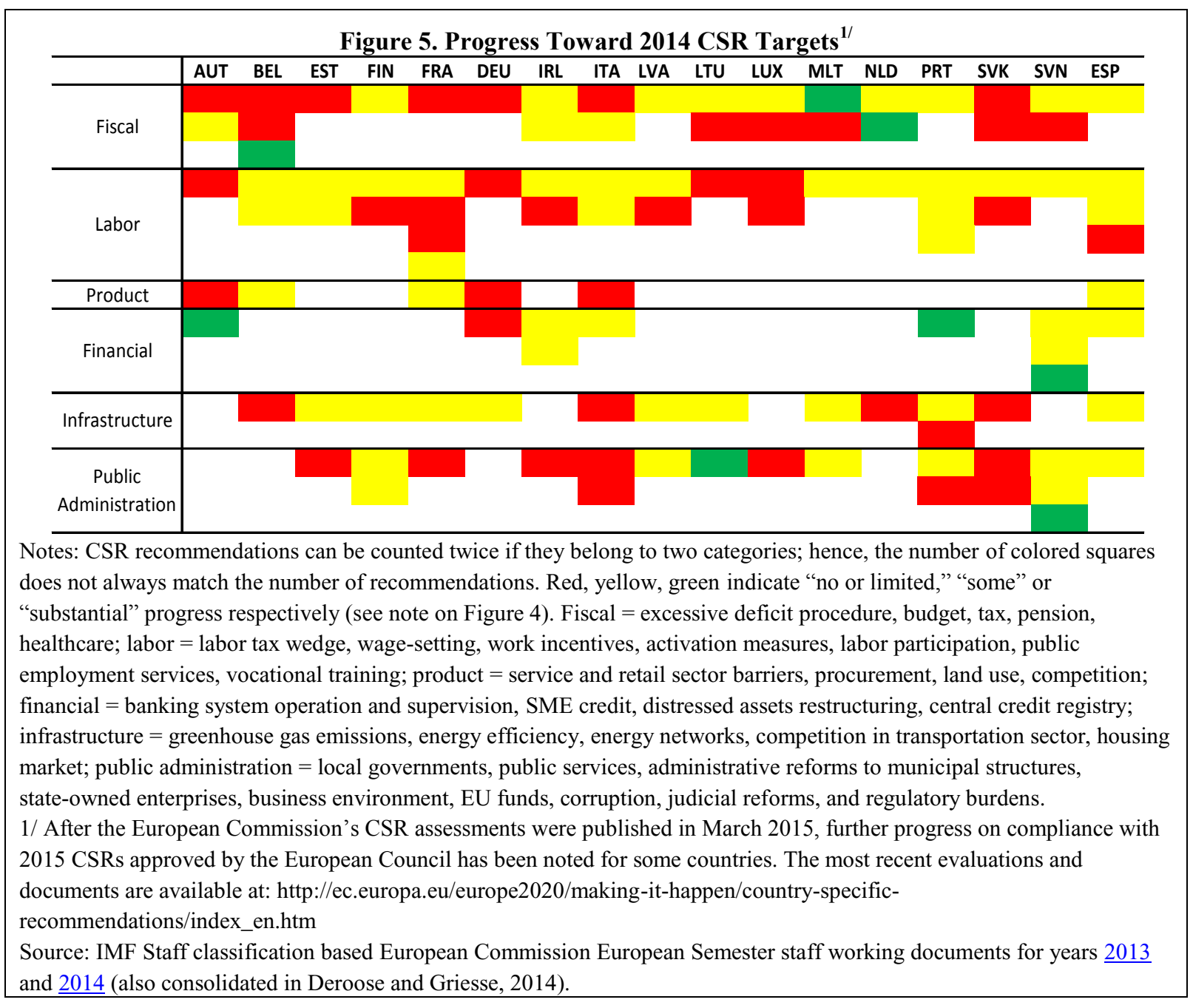

note that "there are significant political obstacles [to completing the Single Market] despite the enormous economic potential associated with [it]." The ability of EU institutions to incentivize reforms has been hampered by:

- The limited incentives of member states to pressure their peers, especially for reforms where wider and cross-border implications are unclear. Countries may also refrain from pressuring others in the hope of avoiding pressure themselves.

- The EU's enforcement powers are not sufficiently strong or preemptive. The EU cannot compel compliance as CSRs are not legally binding; it is up to member states to design and implement reforms. The EC and the Council can propose, monitor and assess reforms and outcomes, as well as issue warnings and recommendations when reforms are not consistent with the broad guidelines or risk jeopardizing the monetary union. The EU can impose sanctions on euro areas countries, but only after the EIP has been triggered and the member 
state is already in difficult financial or economic straits, thus limiting the EU's capacity to preempt imbalances from arising.

- The EC has held back in applying the enforcement tools at its disposal (ECB, 2015b, Box 5). Since 2011, the EC has full discretion in recommending that an EIP be launched or when judging insufficient action. ${ }^{12}$ To date, the EIP has never been opened—and thus no sanctions have been imposed - even though several countries have been diagnosed with excessive imbalances (Spain and Slovenia (2013); Italy, Croatia, and Slovenia (2014); and, Bulgaria, France, Croatia, Italy, and Portugal (2015)). In these cases, the EC stepped up recommendations and monitored policy actions in member states by means of an enhanced process of "specific monitoring" which foresees bi-annual missions and reporting. The EIP was not opened as the EC considered the policies outlined in revised national reform programs and stability or convergence programs to be appropriate for addressing the imbalances. Similarly, under the SGP, there are few precedents of the EC proposing "no effective action." Thus, the system of semi-automatic sanctions available under the current framework (Box 1) has not resulted in any actual sanctions, although it could be argued that it is the prospect of sanctions that has incentivized countries to take action.

\section{Three Proposals to Strengthen InCentives}

“... closer coordination of economic policies is essential to ensure the smooth functioning of the Economic and Monetary Union ... [there is a need to] develop concrete mechanisms for stronger economic policy coordination, convergence and solidarity. ” EU Summit, October 2014

Any proposal to strengthen the implementation of structural reforms in the euro area would need to improve the traction of the EU governance framework, as the EU-more so than member states - is likely to be the more effective champion for reforms that serve the broader interest of the monetary union (see page 5). To this end, the EU framework would need to provide better incentives for the implementation of reforms. Any proposal to foster structural reforms would also need to address the challenges highlighted in the previous sections, while being respectful of current jurisdictional boundaries (i.e., assuming a Treaty change is not imminent and therefore the EU's mandate on structural reforms is likely to remain constrained). Thus, the

\footnotetext{
${ }^{12} \underline{\mathrm{http}: / / \mathrm{ec} . \text { europa.eu/transparency/regdoc/rep/3/2014/EN/3-2014-9005-EN-F1-1.Pdf }}$
} 
proposals would need to improve member state ownership of reforms, help alleviate the political costs of reforms, and reduce excessive discretion in the enforcement of the current framework.

\section{Box 1. Financial Sanctions Within the Governance Framework}

Semi-automatic sanctions are part of the enforcement toolkit, but the provisions vary across the framework:

EIP. For euro area countries under the EIP, financial sanctions can be applied for an insufficient CAP or non-compliance with actions included in the CAP. If the EC recommends sanctions, the Council considers the decision on the basis of reverse qualified majority voting (RQMV), i.e., sanctions can be applied semi-automatically.

SGP flexibility. Failure to implement structural reforms agreed under the SGP can lead to sanctions as well as suspensions of European Structural and Investment (ESI) funds under the EDP. Under the SGP's preventive arm, countries can receive a warning and ultimately a financial sanction in the form of an interest-bearing deposit (Council decision by RQMV) if the failure to implement structural reforms under SGP flexibility results in a significant deviation from the medium-term objective or the path towards it. Under the corrective arm, such a failure could be considered an aggravating factor when assessing effective action, leading to stepped-up procedures with a temporary suspension of parts of ESI funds (RQMV decision for the adoption of the first sanction). Persistent non-compliance could to lead to financial sanctions of up to 0.7 percent of GDP for euro area countries.

ESI funds. In the 2014-2020 programming period, ESI funds are more closely aligned with structural reform priorities and countries are encouraged to program the use of ESI funds to support the implementation of CSRs. Since 2015, ESI funds can be reprogrammed at the EC's request and may be suspended for failure to take effective action under the EDP and/or the EIP. The EC is legally obliged to propose suspension of payments or commitments if the conditions for suspension are met. Payments are only suspended in case of significant non-compliance and if immediate action is sought.

\section{The three complementary and interrelated proposals presented below: "outcome-based"} structural reform benchmarking; better use of existing EU processes; and improving incentives - could help address some of the above concerns. Figure 6 schematically

illustrates the proposals, which are elaborated further in subsequent sections.

- Pros. These proposals are feasible in that they may not necessarily require Treaty changes. The proposals are also realistic in that they are derived from cross-country evidence of what has worked well so far, including in the EU. The proposals would not eliminate all the complexity in the current framework, but they would simplify the operation of the current 
framework without adding additional layers of bureaucracy and processes. It would do so by ensuring greater specificity, transparency, and consensus in setting the reform agenda, which in turn would improve accountability and traction, help reduce excessive discretion in the application of the governance framework, level the playing field across the membership, and provide member states with the necessary support to take politically difficult actions.

- Cons. The proposals may run into political and operational hurdles. But these are not insurmountable and efforts to do so would be an improvement over the status quo. The recent Five President's Report (Juncker et al., 2015) contains similar proposals and therefore constitutes an important first step toward garnering a broader political consensus.

\section{Greater clarity and simplicity in the current EU governance framework would enhance}

the impact of the above proposals and is, therefore, desirable. To the extent simplification does not require Treaty changes, they should start being implemented; and some efforts to streamline processes are already underway. This could be helpful in explaining the context for EU-led reforms including in areas where the EU's role is currently subject to interpretation (e.g., labor and social policies).

Figure 6. Three Complementary Proposals for Strengthening the Governance of Structural Reforms: An Illustration

Council [Member States] and Parliament Agreement

- Area-wide structural reform priorities

- Outcome-based benchmarks under policymakers' control
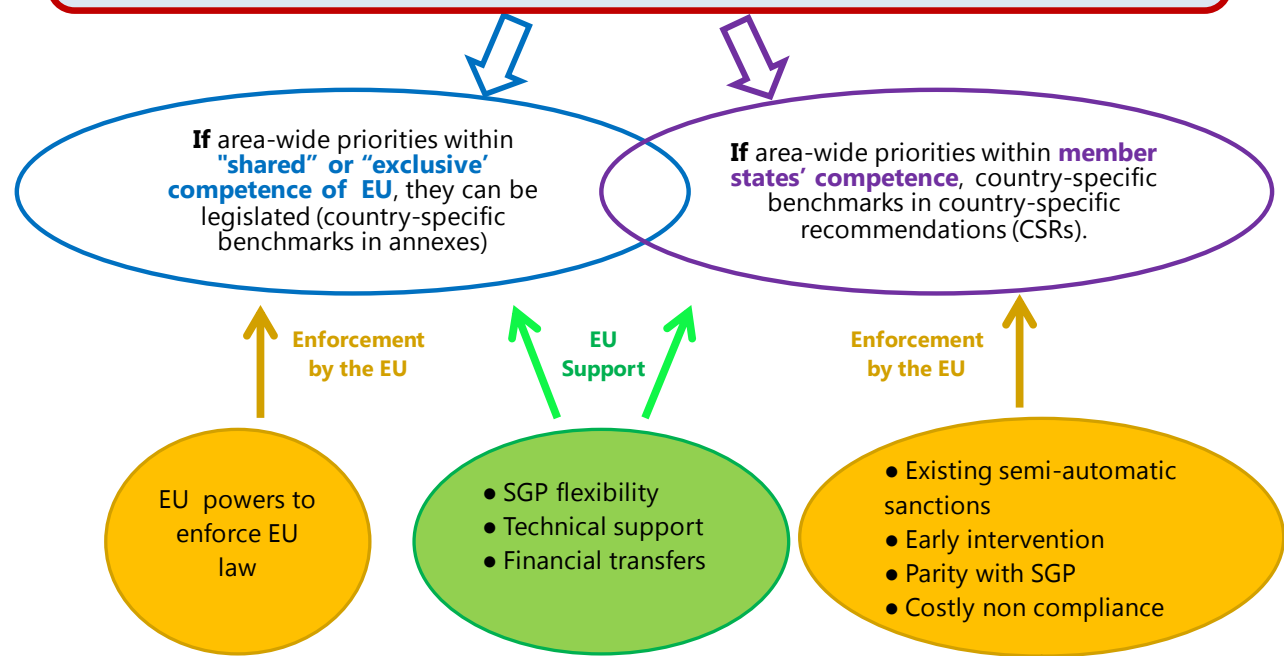

Enforcement by the EU

semi-automatic sanctions

- Early intervention

- Parity with SGP

- Costly non compliance 


\section{A. Proposal 1: Shifting to "Outcome-based" Benchmarks on Area-wide Priorities}

"The next step is to restart the convergence process in the euro zone in a sustainable way to lift growth potential...this requires benchmarking against best practice.” J. Dijsselbloem, April 2015

Benchmarking is not new. As far back as December 2003, the EU Council of Ministers adopted a shortlist of 14 structural indicators to be used in assessing national reform programs (Ioannou et al., 2008). Benchmarks were under consideration during the 2010-11 EU governance reforms. The OECD Going for Growth reports (e.g.,OECD, 2015) has also relied on cross-country comparisons of structural policy and performance indicators for a decade now. More reent proposals have been made by Padoan and Schäuble (2014), Dijsselbloem (2015) and Juncker et al. (2015), whereas Draghi (2014) argues for greater specificity in reforms.

In contrast to many of the benchmarks used so far, "outcome-based" benchmarks would, as the name suggests, focus on measures of reform outcomes. They would also need to be sufficiently concrete, measurable, and directly under the control of policymakers. Figure 7 and Table 1 provide examples of possible benchmarks that could be considered.

Which reforms should the EU benchmark? The EU should have the ability to enforce reforms that achieve two goals (Draghi, 2014). The first goal would be to allow member states to thrive independently within the monetary union. This would require reforms that increase growth, competitiveness and productivity, improve the efficiency of public administration, and ultimately reduce vulnerabilities at the national level. The second goal would be to complete the Single Market to improve the resilience of the monetary union and foster further convergence in the absence of common area-wide public sector risk-sharing. This would include reforms that achieve sufficient flexibility in factor markets and greater private sector risk-sharing to enable a faster adjustment to shocks. Some reforms can contribute to achieving both objectives. Thus, outcome-based benchmarks could focus on priority reforms that further convergence (such as a common energy market, integration of services markets, or digital networks) and that improve 
national productivity, competitiveness, the business climate and resilience to shocks (such as harmonizing and reducing the cost of doing business or the time it takes to enforce contracts). ${ }^{13}$

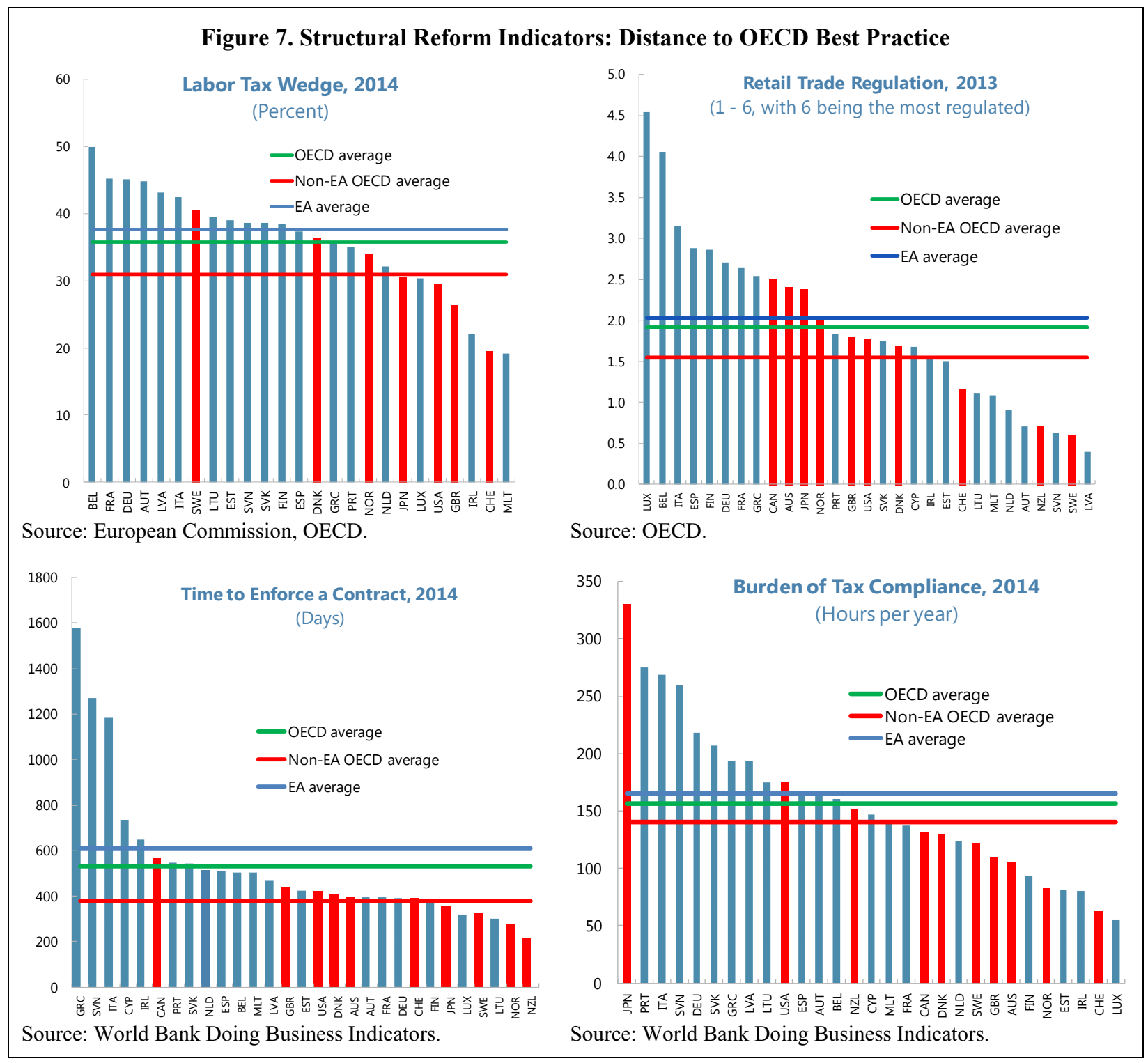

\section{EU institutions could specify ambitious area-wide outcome-based benchmarks, ideally} based on regional and global best practices and outcomes (Figure 7). To improve ownership

\footnotetext{
${ }^{13}$ Some reforms in areas where greater harmonization may be appropriate (e.g., those related to product markets or public administration) may benefit from benchmarking more than others (e.g., labor market reforms). The issue of choosing priority reform areas for benchmarking is, however, complex and, as discussed before, beyond the scope of this paper.
} 
and traction, area-wide benchmarks would need to be given political legitimacy by the Council (and thereby the member states), and the European Parliament (step 1 in Figure 6). Setting and enforcing area-wide benchmarks may be legally easier in areas of "exclusive" and "shared" competence than in the areas where the EU is restricted to coordination. But even in the latter case, there is scope for greater specificity and benchmarking. Illustratively, if there is political consensus among EU member states that the time to enforce contracts in the EU should be reduced as a matter of priority, then the relevant OECD indicator could be used as a benchmark. And the target could be set in an ambitious manner, say, well below the blue horizontal line which shows the euro area average, and closer to the red line which is the average of non-euro area OECD countries.

\section{Advantages of outcome-based benchmarking}

The shift to outcome-based targets would have a number of benefits. It would make the reform agenda simpler and more specific in nature, thereby increasing transparency and accountability regarding the implementation and enforcement of reforms. In addition, benchmarking could lead to:

- Greater ownership and buy-in. The failure to implement CSRs is sometimes attributed to the top-down nature of the recommendations. Agreement on area-wide benchmarks at the political level (Council and Parliament) could help foster ownership and help reduce the perception of an overbearing EU as member states would be involved in setting these benchmarks, reflecting a collective commitment. Benchmarking could also help focus attention on a limited number of crucial reform priorities, such as those that raise national productivity and help create a Single Market. and encourage popular buy-in for reforms (and limit political repercussions) by focusing the policy debates on desired outcomes. Member states would work with the EU to define a feasible but ambitious timeframe for transitioning to the area-wide benchmarks. Finally, they would have leeway in how they achieve targeted outcomes in that they would be able to develop their own action plans to achieve area-wide goals. 
Table 1. Possible Outcome-Based Benchmarks on Area-Wide Priority Reforms

\begin{tabular}{|c|c|c|}
\hline $\begin{array}{l}\text { Productivity and Market } \\
\text { Flexibility (National) }\end{array}$ & Qualitative Indicators & Quantitative Indicators \\
\hline Labor market flexibility & $\begin{array}{l}\text { - OECD Employment Protection Index } \\
\text { - Nature of collective bargaining agreements } \\
\text { (e.g., industry-level, firm-level, etc.) }\end{array}$ & $\begin{array}{l}\text { - Labor tax wedge } \\
\text { - Share of involuntary temporary contracts } \\
\text { - Unemployment and inactivity "traps" } \\
\text { - Benefit replacement rates } \\
\text { - Ratio of minimum to median wages } \\
\text { - Collective bargaining agreement coverage }\end{array}$ \\
\hline $\begin{array}{l}\text { Improving the business } \\
\text { environment }\end{array}$ & $\begin{array}{l}\text { - Global Competitiveness (GC) indicators of } \\
\text { quality of institutions, infrastructure, } \\
\text { technological readiness, etc. }\end{array}$ & $\begin{array}{l}\text { - Transport network density } \\
\text { - WBDB (e.g., number of days to enforce a contract } \\
\text { or complete insolvency proceedings) }\end{array}$ \\
\hline Product market flexibility & $\begin{array}{l}\text { - OECD Product Market and Network } \\
\text { Regulation Indicators } \\
\text { - GC indicators of goods market efficiency } \\
\text { - Tariff and non-tariff barriers } \\
\text { - EU Single Market Scoreboard indicators } \\
\text { - Barriers to cross-border flow of services }{ }^{1}\end{array}$ & $\begin{array}{l}\text { - Measures of market concentration (e.g., } \\
\text { Herfindahl-Hirschman Index) } \\
\text { - Cost of starting a business (a component of WB } \\
\text { Doing Business Indicators (WBDB)) } \\
\text { - EU Justice Scoreboard }\end{array}$ \\
\hline $\begin{array}{l}\text { Public administration } \\
\text { efficiency }\end{array}$ & $\begin{array}{l}\text { - Government effectiveness (WB Governance } \\
\text { Indicators) } \\
\text { - GC indicators of wastefulness of } \\
\text { government spending }\end{array}$ & $\begin{array}{l}\text { - Use of electronic government } \\
\text { - Number of days to obtain business licenses } \\
\text { - Number of hours to comply with tax rules } \\
\text { - WBDB indicators } \\
\text { - EU Justice Scoreboard }\end{array}$ \\
\hline Pension reforms & & $\begin{array}{l}\text { - Change in net pension wealth } \\
\text { - Gross/net replacement rates }\end{array}$ \\
\hline $\begin{array}{l}\text { Modernizing social } \\
\text { protection }\end{array}$ & & $\begin{array}{l}\text { - Health expenditure } \\
\text { - Net costs of childcare }\end{array}$ \\
\hline Research and innovation & & - Financial support for private $R \& D$ \\
\hline Integration (EU) & Qualitative Indicators & Quantitative Indicators \\
\hline $\begin{array}{l}\text { Single market in goods and } \\
\text { services }\end{array}$ & $\begin{array}{l}\text { - Consumer market scoreboard (EC consumer } \\
\text { evaluations) }\end{array}$ & $\begin{array}{l}\text { - EC Single Market Scoreboard } \\
\text { - Postal services (prices and transit times) }\end{array}$ \\
\hline Energy Union & & $\begin{array}{l}\text { - EC's energy internal market indicators } \\
\text { - Number of interconnections of electricity networks }\end{array}$ \\
\hline Digital Single Market & - Efficiency of digital market (survey data) & $\begin{array}{l}\text { - EC's Digital Agenda scoreboard and the Digital } \\
\text { Economy and Society Index }\end{array}$ \\
\hline \multicolumn{3}{|c|}{$\begin{array}{l}{ }^{1} \text { Barriers to cross-border provision of services were identified by the EC on the basis of "mutual evaluations" done by member states } \\
\text { and expert knowledge (see Monteagudo, et al. (2012); an update of this study is expected in late 2015). } \\
\text { Note: The distinction between qualitative and quantitative indicators is primarily based on the underlying data. Thus, indicators relying } \\
\text { primarily on surveys are considered qualitative despite their numerical values. Some indicators (e.g., WBDB) are based on both } \\
\text { qualitative and quantitative information. Net pension wealth is an OECD indicator measuring the incentive to remain in the workforce } \\
\text { for an extended time. } \\
\text { Source: Area-wide reform priorities from European Commission (2014b). }\end{array}$} \\
\hline
\end{tabular}


- Evenhanded effective enforcement. Outcome-based benchmarking would help simplify and better prioritize reforms, as well as facilitate monitoring and pre-emptive corrective action where necessary. The focus would be squarely on the ultimate objective, and by making differences in performance clearly visible and comparable across countries, the new approach would reduce the EC's ability to exercise excessive discretion in utilizing its enforcement tools, increase accountability for action or inaction, and level the playing field across members.

- Enhanced credibility. Outcome-based benchmarking would help allow semi-automatic sanctions to work and would enhance the credibility of sanctions. Benchmarking can also reduce political complications by providing early warning and scope for pre-emptive action as it would improve the EU's ability to push for reforms during good times, well before imbalances become excessive and at a time when countries can weather the impact of adjustment.

\section{Challenges of outcome-based benchmarking}

\section{Determining and quantifying the appropriate benchmarks will not always be}

straightforward. It may be difficult to find specific quantifiable indicators with all the desired characteristics - measurable with a fair degree of certainty, realistic and enforceable, directly under the control of policymakers, as well as closely and strongly linked to the ultimate structural reform objective. Some policy areas may be less amenable to measurement and quantification and may incorporate some element of judgment and subjectivity, but this may not be an insurmountable problem if there is prior collective agreement on the methodology. The following examples illustrate some considerations in setting outcome-based benchmarks:

- A simple case. France's 2014 CSRs included a recommendation to "simplify companies' administrative, fiscal and accounting rules and take concrete measures to implement the Government's ongoing 'simplification plan' by December 2014.” An outcome-based approximation of the same recommendation might be, "reduce the time it takes for a company to comply with tax rules to $\mathrm{x}$ hours" (similar to the indicator compiled by the World Bank), or "make electronic tax filing mandatory." While the suggested benchmarks may be narrower in scope than the original formulation, they have the advantage of being 
focused on a macro-critical outcome, more transparent and easy to monitor, and could conceivably require a broader set of policy actions.

- A more complex case. Another example could be targets on employment rates such as in the Europe 2020 strategy. While these may seem quite specific and outcome-based, the actual employment rate can be difficult to target effectively as it is subject to confounding factors that influence employment but are not entirely under the control of policymakers, such as economic growth. A more easily enforceable target might be one on the labor tax wedge or labor market duality (e.g., "reduce labor tax wedge or labor market duality to x percent in y years") as this can be directly influenced by policy and has been empirically shown to be one of the factors associated with higher employment rates.

Nevertheless, the operational challenges should not be overstated. The structural reform indicators already used by the EU, multilateral institutions, policymakers, and analysts in their surveillance and research could be a good starting point for determining suitable benchmarks. ${ }^{14}$ The EC already uses similar benchmarks for technical analysis of the impact of reforms and progress toward EU Directives (e.g., Monteagudo et. al, 2012 uses World Bank Doing Business Indicators (WBDB) to assess the potential economic impact of setting up national "points of single contact" for services activities and a "closing the gap" approach with best performing EU countries to assess the actual and potential additional impact of the Services Directive). In some cases, benchmarks could be based on indicators that the EU already collects and monitors as well as Eurostat statistics, such as the common methodology for assessing administrative costs posed by regulations (European Commission, 2005). Some of these indicators are produced relatively infrequently at present, and there may be a need for the EU to produce similar (or better) indicators at more frequent intervals. Table 1 provides a non-exhaustive set of potential indicators in EU reform priority areas (European Commission, 2014b).

\section{Translating benchmarks into national policies}

\section{National productivity councils (NPC) could spur innovative policy approaches by providing ex ante support for governments to translate area-wide reform targets into}

\footnotetext{
${ }^{14}$ Benchmarks can be based on: (i) qualitative information relying on questionnaire responses or opinion surveys; (ii) quantitative information; and, (iii) qualitative indicators based on aggregations of quantitative indicators.
} 
national action plans. NPCs and similar entities play a useful role in other countries such as Australia, Belgium, Germany, the Netherlands, and New Zealand, although their design and functions vary (Table 4). ${ }^{15}$ In cooperation with national governments, NPCs could be tasked with designing reforms, monitoring implementation and preliminary outcomes, and proposing amendments to action plans as necessary to achieve the desired outcomes. Governments would be in charge of actual implementation. The dialog between NPCs and governments regarding reform proposals and implementation could improve transparency and help inform the public about the need for and impact of reforms. To the extent that member states have leeway to experiment with different approaches to reach the same goals, they would be "laboratories of democracy." ${ }^{16}$ Some degree of EC participation in NPCs should be considered to facilitate a cross-border dimension to policy discussions.

\section{Cross-country examples and national fiscal councils can provide a template for the} appropriate governance framework for NPCs. It would be important to ensure strict operational independence from politics, accountability, a strong presence in the public debate, and adequate resources (Debrun and Kinda, 2014).

\section{B. Proposal 2: Making More Effective Use of EU Authority}

\section{Benchmarking would improve the operation of the current framework but, in turn, an} effective governance framework can enhance the success of benchmarks. For example, benchmarks proposed in the Lisbon Agenda have been less successful in part because they preceded the 2010-11 EU governance reforms which enhanced the EU's ability to enforce reforms via policy coordination. In contrast, as discussed below, benchmarks proposed in EU Directives have been effectively enforced and the SGP targets, despite their complexity, have supported the conduct of fiscal policy (Andrle et al. 2015).

But how should benchmarking be introduced into the current EU governance framework? And, could existing processes be improved further to enhance structural reform implementation? This

\footnotetext{
${ }^{15}$ Also advocated by Allard et al., 2010. More recently, Sapir and Wolff (2015) propose the creation of a network of independent national competitiveness councils (modeled after Belgium) at the level of the euro area to ensure that wage developments are in line with those in trading partner countries and prevent competitiveness problems.

${ }^{16}$ Portugal's 2014 CSR measure for "a functionally independent central evaluation unit at the government level, which assesses and reports every six months on the implementation of these reforms, including consistency with the ex-ante impact assessment, with corrective action if needed" goes in this direction.
} 
is worth discussing as the jurisdictional authority and the enforcement power of EU institutions vary across the main elements of the governance framework.

\section{Legislating priority reforms}

\section{Directives and Regulations specifying concrete targets generally have a good track record} in achieving desired outcomes (Table 2). Therefore, for priority reforms, area-wide benchmarks should be implemented via EU legislation, especially to further convergence where the necessary political consensus has already been achieved (Figure 6). If there is political willingness, this would be feasible in areas of "exclusive" and "shared" competence, and would give the EU the power to push for faster progress on product market reforms as well as EU-wide initiatives to build a single market for services, capital, energy, transport and the digital sector. Legislation can also be used to benchmark reforms in areas where the EU has power to coordinate.

\begin{tabular}{|l|l|}
\hline \multicolumn{2}{|c|}{ Table 2. Examples of Outcome-Based Directives and Regulations } \\
\hline Directives/ Regulations & Targets and Benchmarks \\
\hline Late Payment Directive & $\begin{array}{l}\text { Harmonize the time for public authorities to pay businesses to } 30 \\
\text { days (60 days if exceptional circumstances), and for businesses to } \\
\text { pay other businesses to } 60 \text { days (unless agreed otherwise). }\end{array}$ \\
\hline Deposit Guarantee Scheme (DGS) Directives & $\begin{array}{l}\text { Increase minimum protection for bank deposits to } € 100,000 . \\
\text { Reach a target level for ex ante funds of DGS of } 0.8 \% \text { of their } \\
\text { covered deposits (i.e., about } € 55 \text { billion) to be reached within } 10 \\
\text { years (4 year extension in exceptional circumstances). }\end{array}$ \\
\hline EU energy package: Renewable Energy Directive & $\begin{array}{l}\text { At least a 20 \% share of energy from renewable sources in EU } \\
\text { gross final consumption of energy in 2020. }\end{array}$ \\
\hline $\begin{array}{l}\text { Clean Power for Transport package: Deployment of } \\
\text { alternative fuels infrastructure Directive }\end{array}$ & $\begin{array}{l}\text { Common technical specifications for recharging and refueling } \\
\text { stations. }\end{array}$ \\
\hline Connected Continent package: Roaming Regulation & Maximum tariffs for calls, texts, and data downloads. \\
\hline
\end{tabular}

A legislative approach has several advantages. EU legislation would imply stronger enforcement powers than coordination mechanisms, because legislation, once adopted, must be implemented. Legislation may also be particularly helpful in harmonizing practices and laws to complete the Single Market. And it could strengthen the hand of national governments in pushing through reforms against opposition from local vested interests. It could also promote investor confidence as uniform EU legislation would be easier to navigate than several national laws, and EU laws may be less susceptible to reversals than national legislation. Outcome-based legislation can also foster greater buy-in for reforms by clarifying expectations and providing scope for evenhanded application of sanctions for non-compliance across all euro area members. 
However, a legislative approach may not be appropriate for every reform. The choice would depend on the specific policy area and on whether the EU has powers to legislate in that area. For example, a legislative approach to improving insolvency regimes in the euro area could take many forms. It could comprise an EU insolvency law (Regulation) replacing national laws (but this may be outside the EU's jurisdiction); the specification of a list of best practices that all national insolvency laws should adhere to (a Recommendation ${ }^{17}$ ); or, the specification of outcomes that would need to be delivered within the parameters of national laws (harmonization via a Directive). Moreover, legislation would require political consensus, which can take time, and it may be resisted by non-euro area countries to which it would also apply.

\section{The legislative approach can be consistent with the current EC initiative to reduce} excessive legislation and red tape. In fact, these objectives may reinforce each other by better prioritizing reforms where greater harmonization is needed, and avoiding or removing unnecessary legislation that distracts from important policy goals. Smarter use of legislation would also help clarify the role of EU institutions vis-à-vis member states, allowing it to act selectively but forcefully on matters that have a bearing on the functioning of the EMU.

\section{Policy coordination with more teeth}

\section{Since euro area countries have vastly different starting points, they may need to transition} to area-wide benchmarks at different speeds. Complementing the legislative approach, CSRs could focus on country-specific intermediate benchmarks that measure progress toward the desired area-wide benchmarks (Figure 6), such as the national targets to achieve Europe 2020 headline goals. This would simplify CSRs, making them more focused, specific, and transparent, in contrast with past CSRs which have, until 2014, on average comprised between 4-8 major recommendations per country, with several sub-recommendations (Table 3). ${ }^{18}$ Outcome-based CSRs would be easier to monitor and could increase ownership of CSRs through member state endorsement of the area-wide benchmarks.

\footnotetext{
${ }^{17}$ For example, the EC issued a recommendation on some aspects of business failure and insolvency in March 2014.

${ }^{18}$ CSRs have been streamlined in 2015 .
} 


\section{Existing processes could be used more effectively to facilitate peer comparison and}

competition. The EC already rates progress under the CSRs on a five-category scale (no/

limited/some/substantial progress, or fully implemented). A streamlined public summary

dashboard summarizing scores on performance toward benchmarks could provide a picture of

the overall track record for reforms, allow better differentiation of country risk and prospects, and could increase the pressure on countries to reform. Such a system may be particularly useful in pressuring the larger countries to reform in order to preserve their relative standing among peers.

\begin{tabular}{|c|c|c|}
\hline \multicolumn{3}{|c|}{ Table 3. Alternative Specification of 2014 CSR Recommendations: Some Examples } \\
\hline Country & 2014 CSR recommendations & Approximate outcome-based benchmarks \\
\hline France & $\begin{array}{l}\text { Simplify companies' administrative, fiscal and accounting rules } \\
\text { and take concrete measures to implement the Government's } \\
\text { ongoing 'simplification plan' by December } 2014 \text {. }\end{array}$ & $\begin{array}{l}\text { Reduce administrative burden on companies (or } \\
\text { time it takes to file taxes) to } \mathrm{X} \text {, where } \mathrm{X} \text { is a } \\
\text { WBDB indicator. }\end{array}$ \\
\hline France & $\begin{array}{l}\text { Remove unjustified restrictions on the access to and exercise of } \\
\text { regulated professions and reduce entry costs and promote } \\
\text { competition in services. }\end{array}$ & $\begin{array}{l}\text { Ensure that costs of starting a business do not } \\
\text { exceed X percent of income (WBDB); Reduce } \\
\text { barriers to cross-border provision of services to } \\
Y^{2}\end{array}$ \\
\hline Italy & $\begin{array}{l}\text { Monitor in a timely manner the impact of the reforms adopted to } \\
\text { increase the efficiency of civil justice with a view to securing } \\
\text { their effectiveness and adopting complementary action if needed. }\end{array}$ & $\begin{array}{l}\text { Ensure that civil disputes can be settled in } \mathrm{X} \text { days } \\
\text { and/or } \mathrm{Y} \text { cost in percent of claims, where } \mathrm{X} \text { and } \mathrm{Y} \\
\text { are WBDB indicators. }\end{array}$ \\
\hline Italy & $\begin{array}{l}\text { Adopt effective action to promote female employment, by } \\
\text { adopting measures to reduce fiscal disincentives for second } \\
\text { earners by March } 2015 \text { and providing adequate care services. }\end{array}$ & $\begin{array}{l}\text { Ensure that marginal tax rates when switching } \\
\text { from inactivity to unemployment (inactivity traps) } \\
\text { are no more than X percent. }\end{array}$ \\
\hline Portugal & $\begin{array}{l}\text { Maintain minimum wage developments consistent with the } \\
\text { objectives of promoting employment and competitiveness. }\end{array}$ & $\begin{array}{l}\text { Ensure that the ratio of minimum to median wage } \\
\text { does not exceed } \mathrm{Y} \text {. }\end{array}$ \\
\hline Spain & $\begin{array}{l}\text { Address unjustified restrictions to the establishment of large- } \\
\text { scale retail premises, in particular through a revision of existing } \\
\text { regional planning regulations. }\end{array}$ & $\begin{array}{l}\text { Ensure planning permissions can be obtained } \\
\text { within X days or, that the number of procedures } \\
\text { for obtaining construction permits is no more than } \\
Y \text {, where } X \text { and } Y \text { are WBDB indicators. }\end{array}$ \\
\hline Germany & $\begin{array}{l}\text { Reinforce efforts to accelerate the expansion of the national and } \\
\text { cross-border electricity and gas networks. }\end{array}$ & $\begin{array}{l}\text { Ensure that electricity and gas networks have a } \\
\text { minimum of X interconnections. }\end{array}$ \\
\hline Austria & $\begin{array}{l}\text { Reduce the high tax wedge on labor for low-income earners by } \\
\text { shifting taxation to sources less detrimental to growth, such as } \\
\text { recurrent taxes on immovable property, including by updating } \\
\text { the tax base. }\end{array}$ & $\begin{array}{l}\text { Ensure that the labor tax wedge is no more than } \mathrm{X} \\
\text { percent. }\end{array}$ \\
\hline \multicolumn{3}{|c|}{$\begin{array}{l}{ }^{1} \text { Alternatively the common methodology used in the EU to assess the impact of regulations, especially administrative costs, could } \\
\text { be used (European Commission, 2005). } \\
{ }^{2} \text { The assessment of barriers could be based on Monteagudo, J. et al., (2012). } \\
\text { Source: European Commission; IMF Staff Proposals. }\end{array}$} \\
\hline
\end{tabular}

\section{Reforms take time to implement and bear fruit, and should ideally be implemented in good times when it is possible to cushion redistributive effects. Moreover, sanctions may lack} credibility in a downturn. Thus, reforms should be encouraged well before imbalances become excessive and economic circumstances deteriorate. Extending the EU's powers to sanction countries under the preventive arm of the MIP, similar to the SGP, and making CSRs legally 
binding could achieve this goal and also simplify the framework. However, penalties under the preventive arm and legally binding CSRs may violate the principle of "proportionality" as long as there is no change in the Treaty and the EU's powers in the relevant areas are restricted to coordination. In these circumstances, preemptive action to stem imbalances from arising would entail the EC taking progress toward CSR structural benchmarks into consideration when triggering the EIP.

\section{Ensuring transparency and accountability of EU institutions}

Greater powers for $\mathrm{EU}$ institutions ought to come with greater ex post accountability, in part to address the perceived "democratic deficit" (lack of control over EU decisions). The EC's discretion increased after the Two-pack, the Six-pack, and the Treaty on Stability, Coordination and Governance (TSCG) without a corresponding increase in checks and balances. A Chief Economic Analyst (CEA) was appointed in 2012 to review ex ante the EC's application of the rules; however, these reports are addressed only to the Commissioners and are not public. An independent evaluation process, governed by the Parliament, of the EC's monitoring and enforcement of the governance framework could be considered, with a presumption of publication of assessments and reviews. The evaluation should be independent of the EC and operationally at arm's length from the Council and the Parliament.

\section{Proposal 3: Strengthening Financial Incentives}

\section{Member state and EU budgets may be able to play a useful role in fostering reforms by} mitigating the distributive effects of structural reforms, offsetting the potential short-term economic costs of reform, and facilitating the necessary political consensus. Indeed, Buti, Röger, and Turrini (2009), and Buti, Turrini, and van den Noord (2014) show that reformists are more likely to be re-elected when mechanisms to soften potentially adverse consequences of the reforms exist, including efficient social safety nets.

\section{Making full use of SGP flexibility to support reforms}

The EU should make full use of SGP flexibility while safeguarding the fiscal framework (Box 2); "outcome-based benchmarking" can be helpful in this regard. 


\section{Box 2. Structural Reforms and the SGP}

The structural reform clause under the preventive arm of the SGP requests the Council and the EC to take into account the implementation of structural reforms which have a verifiable impact on the long-term sustainability of public finances when assessing progress toward the medium-term budgetary objective (MTO). Under the corrective arm of the SGP, the EC can take into account structural reforms when recommending or extending a deadline for the correction of an excessive deficit.

The 2011-13 governance reforms enhanced links between the fiscal and structural reform frameworks. Countries under the Excessive Deficit Procedure (EDP) must present an Economic Partnership Program, outlining structural reforms for a durable correction of the deficit, while those receiving EU financial assistance prepare a Macroeconomic Adjustment Program that also includes structural reforms.

In January 2015, the EC provided guidance on applying the built-in flexibility in the SGP for structural reforms. Countries can now secure SGP flexibility for major planned reforms with long-term positive budgetary impact that are "well specified" and have "credible timelines." Under the preventive arm, a maximum deviation from the MTO of 0.5 percent of GDP is allowed, provided this deviation can be made up within four years. Under the corrective arm, the deadlines to meet the 3 percent of GDP deficit target can be extended.

- The EC could identify ex ante which reforms - out of the CSR benchmarks measuring national progress toward area-wide reform goals - could qualify for SGP flexibility. Since CSR benchmarks will have arisen out of a broader bottom-up political consensus across member states, such an ex ante list would help focus the discussion on implementation rather than on the identification of reforms, which has been a particularly difficult challenge in using SGP flexibility provisions. Where possible, costing estimates could be based on historical experiences and cross-country estimates. For example, previous research suggests that a 1 percentage point cut in the tax wedge is, on average, associated with a revenue loss of 0.3 percent of GDP per year (IMF, 2014b, Figure 8.1) and active labor market policies (ALMP) during reform episodes have cost, on average, about 1 percent of GDP (Figure 8.2). These numbers could be the basis for establishing the impact of labor market reforms on fiscal accounts.

- To ensure that flexibility for "permanent" reforms will not compromise the integrity of the SGP framework, countries could pre-commit to binding compensatory fiscal measures in a multi-year framework if agreed structural reforms are not implemented or if the expected returns do not materialize in the specified timeframe. Such "safeguard" clauses have been used in Italy's 2015 budgetary plans. Medium-term expenditure frameworks with rolling 
spending limits could also be considered (e.g., Sweden). Alternatively, flexibility could be provided on a post hoc basis for reforms by the EC (see first bullet). An outcome-based specification of reforms could reinforce this process.

- Extending the 0.5 percent of GDP fiscal space for structural reforms to countries under the corrective arm (i.e., to all countries) would simplify and clarify procedures and help focus the discussion on reform implementation rather than whether or not these flexibility provisions are applicable. These changes could be considered in the context of reforms to the fiscal framework (such as merging the preventive and corrective arms of the SGP).

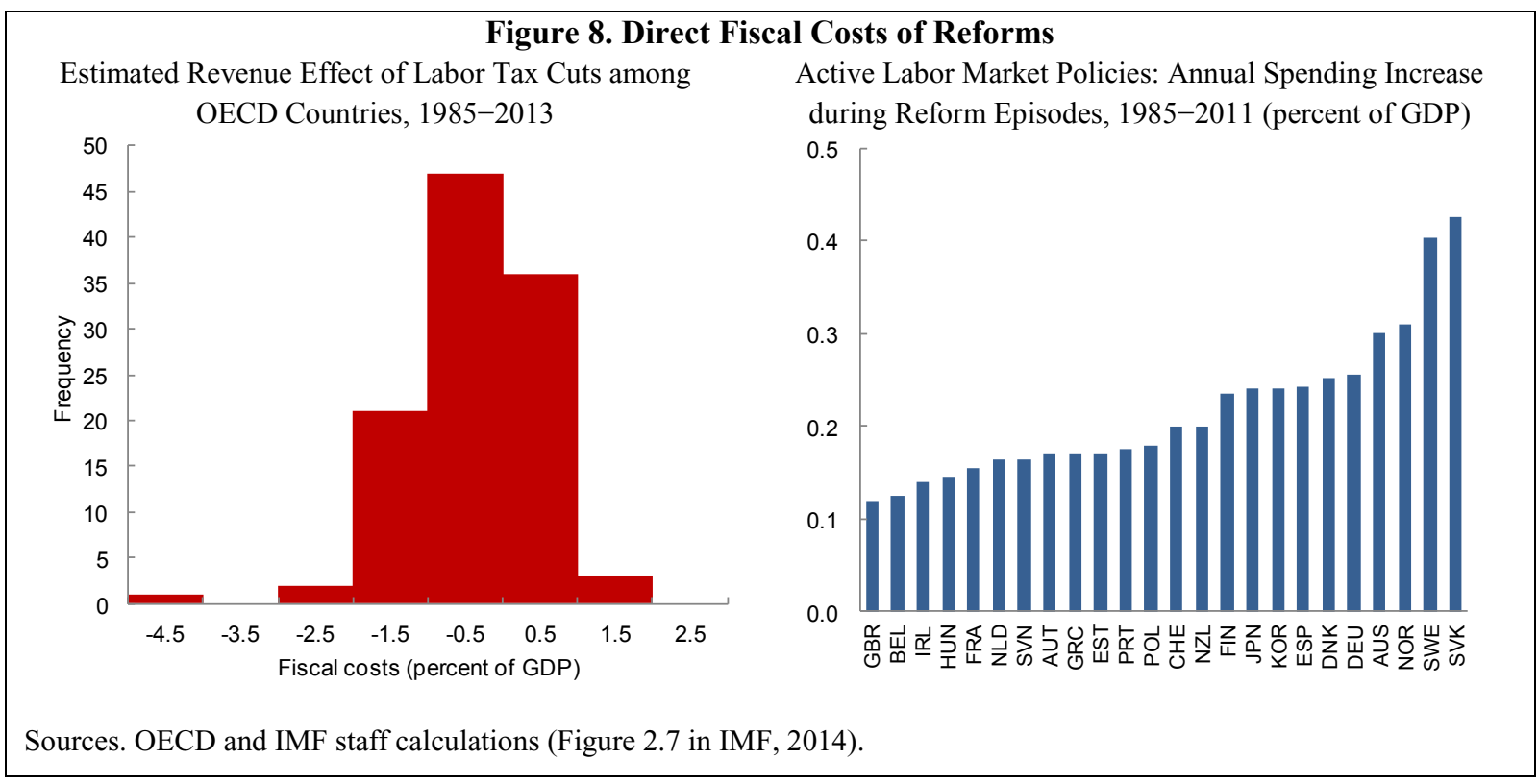

The budget may also be able to play a useful role in fostering reforms that do not have a direct and measurable effect on the budget. A broader category of reforms should, therefore, be permitted under the framework, for example, allowing SGP flexibility to be targeted toward providing appropriate compensation for those affected by reforms to help overcome political obstacles or to expedite implementation (e.g., a limited window of tax incentives to accelerate the restructuring of balance sheets by banks and corporations). Reforms to increase competition could also generate fiscal costs in the form of additional spending on unemployment benefits or support for vocational training or active labor market policies (ALMPs) (Figure 9). For example, a number of countries, including France (1987) and Denmark (1995), accompanied the relaxation of employment protection with more generous unemployment benefits (Figure 9, 
panels 1 and 2) with costs ranging from 0.1-0.25 percent of GDP in France to 1 percent of GDP in Denmark (Beetsma and Debrun, 2004). Other countries have encouraged participation in the labor force by reducing unemployment benefits (Sweden in 2002; Slovenia in 2006-08) or reducing employment protection (Netherlands in 1994-95; Slovenia in 2006-08; Sweden in 2002) but supported employment creation through cuts in labor taxes (Figure 9, panel 5 to 8)

\section{Finally, countries with good track records could be allowed additional fiscal space to} implement more ambitious reforms. The flexibility provided under the SGP could be increased - more fiscal space and/or a longer time to offset the fiscal cost—in such cases, accompanied by appropriate safeguards for the integrity of the fiscal framework (see above).

This would allow more ambitious and comprehensive reforms with higher growth dividends and better reflect the fact that gains from structural reforms take time to materialize. For instance, it cost Finland 0.8 percent of GDP in higher spending on ALMPs in 1992 to facilitate the reduction of employment protection during the same year and Sweden about 1 percent of GDP of upfront spending to reduce its labor tax wedge during 2007-10. ${ }^{19}$ In addition, a recent OECD study (OECD, 2014) highlighted that economic gains from a comprehensive reform package in France would take 5-10 years to have a sizeable impact on potential growth and generate noticeable fiscal space.

\section{More support from the EU}

\section{Direct financial transfers from the EU could help cover costs and support reform. The} scope for direct fiscal transfers from the EU budget is limited as common agricultural policy and structural funds, which are generally not designed to support structural reforms in member countries, absorb more than 70 percent of the EU budget. Nevertheless, ESI funds could be better prioritized and linked more closely to benchmarks to support priority reforms. Should financial sanctions be applied widely, the proceeds could conceivably be recycled as EU financial transfers to support reforms.

\footnotetext{
${ }^{19}$ In some cases, the combination of reforms to offset their fiscal costs was part of a broader package. For instance in Sweden, in addition to reducing unemployment benefits in 2002, the country also tightened the eligibility and duration of sickness and disability benefits over several phases until 2008 and supported labor force participation through various measures, including labor tax cuts and ALMPs.
} 
Figure 9. Fiscal Costs of Measures Compensating Redistributive Effects of Labor Reforms Employment Protection versus Unemployment Benefits
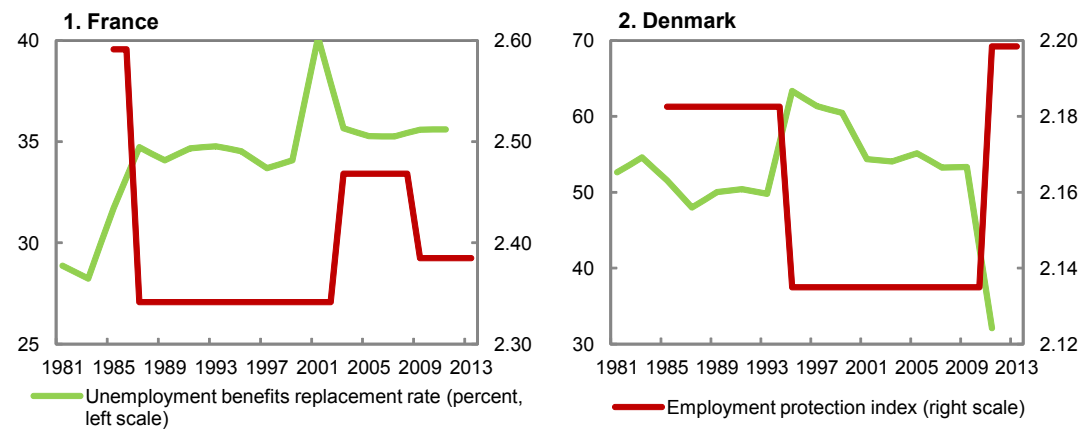

Tighter Employment Protection versus Higher ALMP Spending

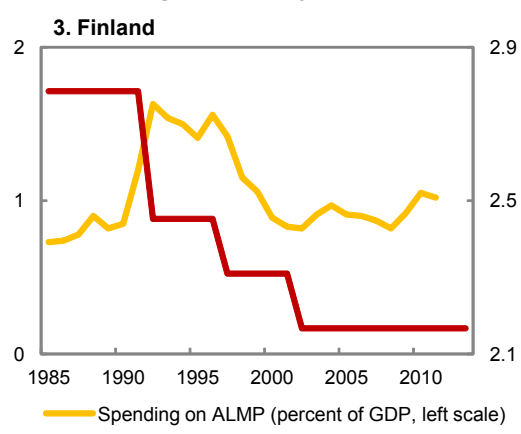

4. Netherlands

Tighter Employment Protection versus Labor Tax Cuts
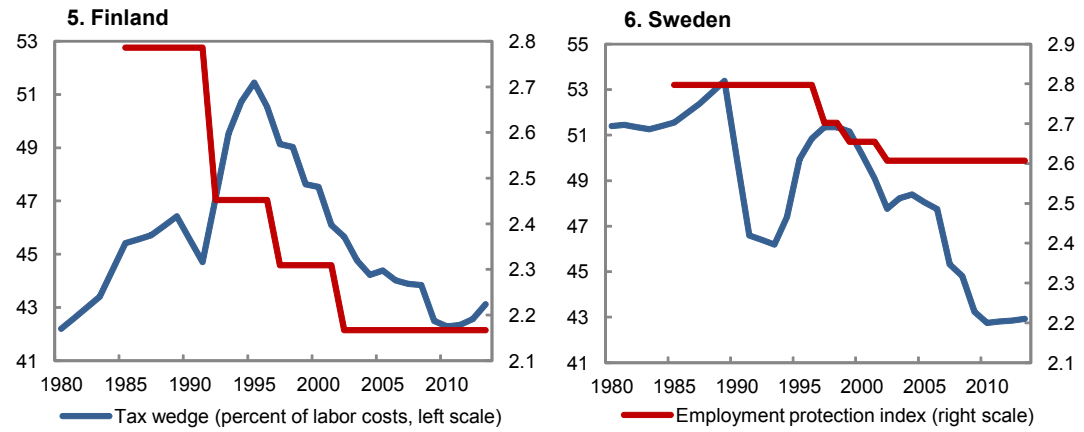
Less Generous Unemployment Benefits versus Labor Tax Cuts
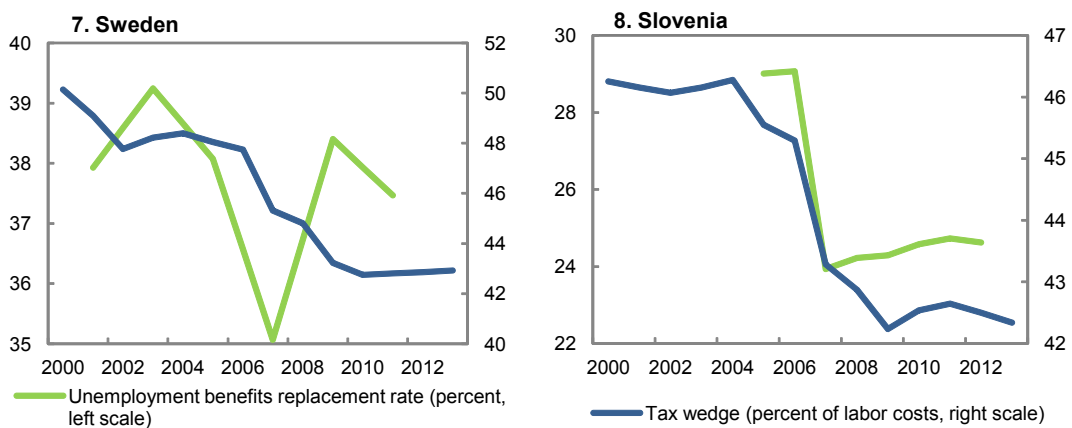

Note. The labor reform index aggregates the labor tax wedge, the unemployment benefits replacement rate, ALMP spending, and the labor protection index. Data on the last two components are only available from 1985. The tax wedge is expressed as a percentage of labor costs (OECD, 2014). ALMPs are aimed to help unemployed people return back to work, including through job placement services, benefit administration, and labor market programs such as training and job creation (OECD, 1994).

Source: Figure 2.8 (IMF, 2014b). 
Financial transfers have been successfully used in other countries to foster the implementation of center-led reforms, including Australia, Finland, Germany, Italy, and the United States. Central governments in Australia and Germany provide financial transfers to local governments to incentivize certain types of reforms or national development plans. For instance, in 2009-2013, the federal government in Australia provided A \$6.7 billion (0.1 percent of GDP) to states conditional on commitments to increase skill levels. In Germany, the federal government is to provide financial relief during 2015-2017 of about $€ 14$ billion ( 0.1 percent of GDP, or 0.35 percent of general government outlays) to the länder and municipalities, with the specific goal of supporting infrastructure investment, education and research. The U.S. federal government also provides grants to incentivize states, e.g., to ensure adoption of federal education standards and to expand low-income health care coverage via Medicaid, including under the Affordable Care Act.

Technical support from the $E U$ could also be helpful in euro area countries that face absorptive and administrative hurdles in implementing reforms, including, for example, the inability to attract the best people to provide the necessary expertise and manage the implementation of reforms. Support from EU institutions can take the form of voluntary technical assistance; EU-wide knowledge hubs with expertise on how to meet targets; or direct funding for experts to design and deliver reforms. In Portugal, for example, tax administration improved significantly after the government revamped top management in the responsible agency. In some countries, EU funding can address absorptive and administrative limits for implementing reforms (e.g., technical assistance as in the Youth Guarantee Scheme). The recently announced "Structural Reform Support Service" goes in this direction (European Commission, Statement/15/5218).

\section{Making non-compliance more costly}

\section{There could be merit in ensuring greater parity with penalties under the SGP framework}

to simplify the governance framework and take into consideration the fact that structural reforms have direct and indirect effects on the fiscal deficit. Non-compliance could be made somewhat more costly by including provisions for non-interest bearing deposits for failure to comply with the EIP, with repeated offenses also triggering enhanced conditionality-based EU monitoring. By increasing transparency, benchmarking could increase the likelihood of these penalties being used, thereby improving incentives to reform. 


\section{Access to ESI funds could be leveraged more effectively by making it conditional on}

reforms. With economic governance conditionality for ESI funds becoming operational in 2015, the EC should make appropriate use of the possibility to reprogram and align the use of ESI funds as closely as possible to the implementation of CSR benchmarks to strengthen the financial incentives for reform (e.g., implementation of the Internal Energy Market legislative package has been linked to ESI Funds). Moreover, where possible, an immediate suspension of payments rather than commitments would be more effective.

\section{Providing meaningful and strong}

incentives for structural reforms will require a much bigger and better

functioning $\mathbf{E U}$ budget, with disbursements closely linked to the full implementation of a set of ex ante agreed measures. Currently, the average annual commitment of ESI financing represents a relatively small share of GDP (Figure 10) for most EU countries except smaller states. In contrast, federal transfers to states in the United States totaled 3.3 percent of GDP in FY 2014 alone. ${ }^{20} \mathrm{~A}$ substantially expanded EU budget—-funded

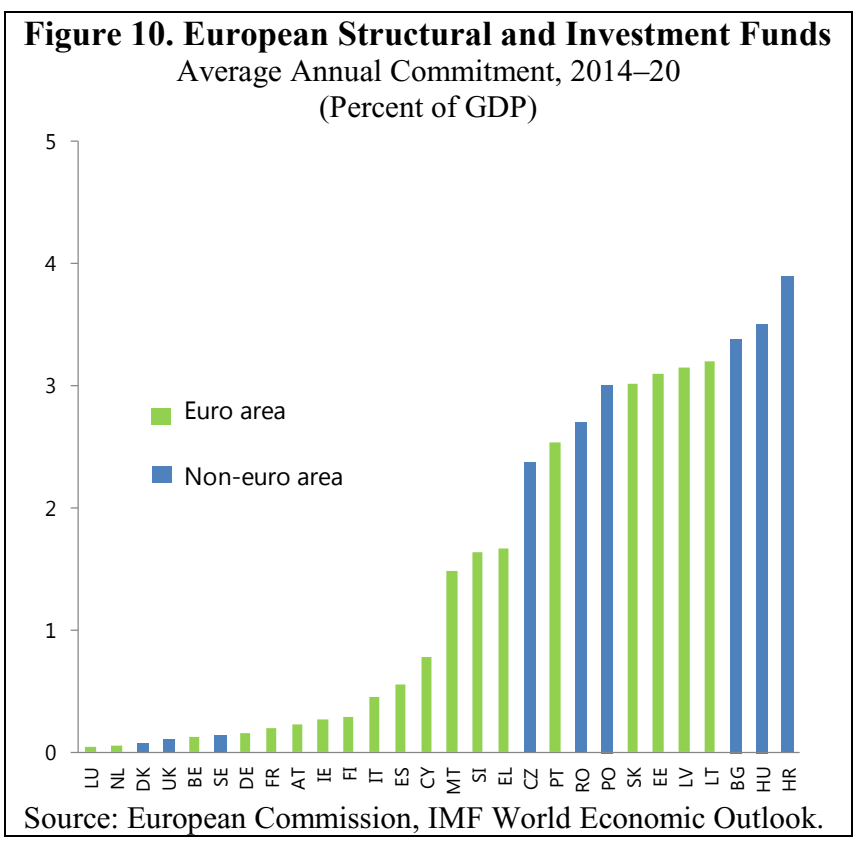

by a dedicated revenue stream for example - might be able to provide direct fiscal transfers to incentivize and support structural reforms in member states, especially the smaller ones, in addition to other benefits such as helping to smooth asymmetric shocks. ${ }^{21}$ The idea of a common euro area fiscal capacity was widely discussed in the context of the Van Rompuy et al. 2012 report, but did not gain political traction at the time. Progress on this front would require political consensus that could be difficult to achieve, but not necessarily a Treaty change.

\footnotetext{
${ }^{20}$ Grants to state and local governments, excluding direct spending by the federal government in states, or taxes paid by state residents to the federal government. Data are from the Office of Management and Budget and the Congressional Budget Office.

${ }^{21}$ Allard et al. (2010) proposed additional EU revenues through EU-wide taxes, e.g., green levies, to provide transfers to incentivize structural reforms in member countries particularly where potential spillovers are large.
} 
Extracting binding commitments from individual countries on achieving reform benchmarks would enhance the legitimacy of sanctions and penalties if they need to be imposed. The commitments should be public, high-level, and sufficiently binding so that there would be a presumption of penalties and sanctions upon failure to meet the agreed outcomes. Requiring that any waivers from sanctions or penalties be fully transparent and a systematic use of a "comply-or-explain" process (Juncker et al., 2015) would enhance the credibility of the framework.

\section{Summary AND The Way ForWard: Moving to a STRUCtUral Union}

"In the medium term...the convergence process towards more resilient economic structures ...should become more binding. This would be achieved by agreeing on a set of common high-level standards that would be defined in EU legislation, as sovereignty over policies of common concern would be shared and strong decision-making at the euro area level would be established."(Juncker et al., 2015)

\section{It is important to keep up the momentum for structural reforms to improve flagging} productivity, sustain and boost the recovery, and build a stronger monetary union. The 2010-11 reforms strengthened the governance framework and provided the EU more scope and authority to push reforms forward, but implementation challenges are evident even at this early stage.

In the near term, the current framework could be made to function better by increasing ownership (by garnering collective political commitment toward ambitious area-wide reforms reflecting priorities such as factor market reforms and improvements in the efficiency of public administration); strengthening existing incentives (via greater specificity, outcome-based benchmarking, transparency and accountability); and providing stronger and evenhanded support for reforms. A simpler framework, dynamic ex ante experimentation with reforms by NPCs, and independent ex post evaluation of the implementation of the governance framework would improve transparency and ownership.

While the above proposals can help promote the implementation of structural reforms in the near term, they bump up against constraints embodied in the Treaty. More fundamental changes to the governance framework could help ensure broader and deeper reforms in euro 
area countries in areas currently outside the EU's jurisdiction, but this may entail further Treaty amendments.

\section{In the medium term, a broader role for the $\mathrm{EU}$ would be essential for ensuring the} resilience of the EMU. In an increasingly complex global economy, addressing economic challenges can require reforms that cut across a broad range of areas. There is evidence of sizable interactions between labor and product market reforms linking the effectiveness of deregulation in one market to the level of regulation in the other market (e.g., Berger and Danninger, 2006; Bassanini and Duval, 2006). The mutually reinforcing effects of structural reforms underscore the need for reforms to be considered together. Therefore, it may be useful to gradually expand the EU's role beyond narrowly defined areas of "exclusive and shared competence" to include other areas that have become critical to the functioning of the union since its ability to achieve goals in one area can depend crucially on policies in another area outside its purview.

Deeper reforms of the governance framework should build on the principles embedded in the near term proposals - namely, greater clarity and specificity in setting the reform agenda; a clearer division of labor between the EU and member states; a greater say of the EU in a broader set of reforms especially if they are critical for the monetary union; less discretion in assessing compliance with benchmarks, but more flexibility in how benchmarks are achieved; and, finally, larger financial incentives for reform, including under the SGP. These reforms should ideally be combined with amendment of the fiscal framework to increase synergies between the two, while reducing overlaps and complexity. Deep political commitment and political capital is required to bring about these changes to the economic governance framework of the EU to ensure the resilience of the monetary union. 


\begin{tabular}{|c|c|c|c|c|}
\hline \multicolumn{5}{|c|}{ Table 4. National Productivity Councils of Australia, Belgium, Germany and New Zealand: A Brief Summary } \\
\hline & $\begin{array}{c}\text { Belgium } \\
\text { Conseil Central de l'Economie, } \\
1948 \\
\end{array}$ & $\begin{array}{c}\text { Australia } \\
\text { Australian Government Productivity } \\
\text { Commission, } 1998\end{array}$ & $\begin{array}{c}\text { Germany } \\
\text { German Council of Economic } \\
\text { Experts, } 1963\end{array}$ & $\begin{array}{c}\text { New Zealand } \\
\text { New Zealand Productivity } \\
\text { Commission, } 2010\end{array}$ \\
\hline Mandate & $\begin{array}{l}\text { Economic organization; dialogue } \\
\text { between employers and workers on } \\
\text { economic issues; guidance to } \\
\text { government on economic policies. } \\
\text { Role has been expanded over time, } \\
\text { making the delivery of opinions or } \\
\text { reports compulsory. Special role in } \\
\text { wage bargaining. }\end{array}$ & $\begin{array}{l}\text { Provides advice on policy or regulatory issues } \\
\text { affecting economic performance and } \\
\text { community wellbeing. Inter alia it contributes } \\
\text { to: improving productivity and overall } \\
\text { economic performance; reducing unnecessary } \\
\text { regulation; developing efficient and } \\
\text { internationally competitive industries; } \\
\text { facilitating adjustment to structural changes in } \\
\text { the economy and avoiding social and economic } \\
\text { hardships arising from those changes; } \\
\text { promoting regional employment and } \\
\text { development. }\end{array}$ & $\begin{array}{l}\text { Provides analysis and general } \\
\text { policy advice, not detailed policy } \\
\text { recommendations. Focuses on } \\
\text { ways to ensure steady, adequate } \\
\text { growth within the framework of } \\
\text { the free market-economy system, } \\
\text { while maintaining high } \\
\text { employment, price stability and } \\
\text { foreign trade equilibrium. }\end{array}$ & $\begin{array}{l}\text { Provides advice to the } \\
\text { government on improving } \\
\text { productivity while supporting } \\
\text { the overall well-being of New } \\
\text { Zealanders. }\end{array}$ \\
\hline Areas covered & $\begin{array}{l}\text { Labor markets; competition policy; } \\
\text { structural policy; sustainable } \\
\text { development; European policy; } \\
\text { sectoral developments; firm-level } \\
\text { governance. }\end{array}$ & $\begin{array}{l}\text { Covers all levels of government and all sectors } \\
\text { of the economy, as well as social and } \\
\text { environmental issues. Topics covered so far: } \\
\text { income distribution; sustainability; } \\
\text { manufacturing productivity; labor costs; } \\
\text { services exports; barriers to setting up and } \\
\text { closing businesses. }\end{array}$ & $\begin{array}{l}\text { Macroeconomic developments } \\
\text { across sectors (labor market, } \\
\text { financial sector, industry, fiscal } \\
\text { and social policy), including at } \\
\text { European level. }\end{array}$ & $\begin{array}{l}\text { Sectors covered so far include: } \\
\text { services; housing; social } \\
\text { services; residential land use; } \\
\text { trade-related matters. }\end{array}$ \\
\hline Members & $\begin{array}{l}\text { Representatives of private sector } \\
\text { trade unions, employers, and } \\
\text { academics. Chaired by a leading } \\
\text { figure independent of the } \\
\text { administration and represented } \\
\text { organizations. }\end{array}$ & $\begin{array}{l}\text { The Board is composed of } 4-11 \\
\text { Commissioners, with relevant qualifications } \\
\text { and experience; at least one Commissioner with } \\
\text { extensive skills and experience in dealing with } \\
\text { the social effects of economic adjustment and } \\
\text { social welfare service delivery, and one in } \\
\text { working in Australian industry. The Chairman, } \\
\text { Deputy Chairman and Commissioners, have } \\
\text { fixed-term appointments. }\end{array}$ & $\begin{array}{l}\text { Consists of five part-time } \\
\text { members (specialists in economic } \\
\text { theory and economic policy) } \\
\text { without political or public-sector } \\
\text { affiliation other than university or } \\
\text { research institutes. Appointed for } \\
\text { renewable five-year terms on the } \\
\text { government's recommendation. } \\
\text { Supported by technical staff. }\end{array}$ & $\begin{array}{l}\text { The Board consists of } 3-4 \\
\text { Commissioners, supported by } \\
15 \text { staff. The founding act lists } \\
\text { no qualification requirements } \\
\text { for members of the } \\
\text { Commission. }\end{array}$ \\
\hline
\end{tabular}




\begin{tabular}{|c|c|c|c|c|}
\hline & $\begin{array}{l}\text { Belgium } \\
\text { Conseil Central de l'Economie, } \\
1948\end{array}$ & $\begin{array}{l}\qquad \text { Australia } \\
\text { Australian Government Productivity } \\
\text { Commission, } 1998 \\
\end{array}$ & $\begin{array}{l}\text { Germany } \\
\text { German Council of Economic } \\
\text { Experts, } 1963\end{array}$ & $\begin{array}{l}\text { New Zealand } \\
\text { New Zealand Productivity } \\
\text { Commission, } 2010 \\
\end{array}$ \\
\hline Powers & $\begin{array}{l}\text { Produces opinions and reports on } \\
\text { particular issues that are binding on } \\
\text { the social partners. In some areas, } \\
\text { the government is required to } \\
\text { request an opinion from CCE. } \\
\text { Special role in wage bargaining: } \\
\text { produces technical report on the } \\
\text { maximum available margin of } \\
\text { growth in labor costs (based on } \\
\text { main trading partners: Germany, } \\
\text { France and the Netherlands) which } \\
\text { provides basis for collective } \\
\text { bargaining agreements. }\end{array}$ & $\begin{array}{l}\text { Conducts public inquiries at the government's } \\
\text { request on policy or regulatory issues bearing } \\
\text { on economic performance and community } \\
\text { wellbeing. Also produces research at } \\
\text { government's request to support its annual } \\
\text { reporting, performance monitoring and other } \\
\text { responsibilities. }\end{array}$ & $\begin{array}{l}\text { Publishes independent reports and } \\
\text { assessments, which have become } \\
\text { essential part of German economic } \\
\text { policy making and have notably } \\
\text { influenced political decisions. } \\
\text { The Council publishes an Annual } \\
\text { Economic Report and also ad-hoc } \\
\text { Special Reports that assess } \\
\text { particular current problems. }\end{array}$ & $\begin{array}{l}\text { Undertakes in-depth inquiries } \\
\text { on topics referred by the } \\
\text { Government. Produces } \\
\text { research on improving } \\
\text { productivity and } \\
\text { Promotes understanding of } \\
\text { productivity issues. }\end{array}$ \\
\hline Independence & $\begin{array}{l}\text { Joint, inter-professional advisory } \\
\text { body, with equal representation of } \\
\text { employers and workers } \\
\text { organizations. Presence of } \\
\text { members known for technical } \\
\text { expertise. President of the Council, } \\
\text { appointed by the King after } \\
\text { consultation with the Council, } \\
\text { independently guides debates. }\end{array}$ & $\begin{array}{l}\text { Commission is an independent advisory body } \\
\text { but a government agency reporting to the } \\
\text { Treasurer. It operates under the powers and } \\
\text { protection of its own legislation, with its own } \\
\text { budget and permanent staff, operating at arm's } \\
\text { length from other government agencies. The } \\
\text { government largely determines its work } \\
\text { program, but the Commission's findings and } \\
\text { recommendations are based on its own analyses } \\
\text { and judgments and are open to public scrutiny. }\end{array}$ & $\begin{array}{l}\text { Since 2005, the Council has } \\
\text { released Occasional Reports on } \\
\text { selected topics upon the request of } \\
\text { the federal government. Reports } \\
\text { do not have to be consensual } \\
\text { among Council members: minority } \\
\text { views can be highlighted and } \\
\text { reports issued if three of five } \\
\text { members agree. The Council may } \\
\text { request hearings with Ministers } \\
\text { and the President of the } \\
\text { Bundesbank. }\end{array}$ & $\begin{array}{l}\text { The government sets inquiry } \\
\text { topics, but the Commission is } \\
\text { required to act independently } \\
\text { in its work. All reports are } \\
\text { made public after presentation } \\
\text { to Parliament. The } \\
\text { Commission evaluates and } \\
\text { reports on its performance and } \\
\text { work once per year. }\end{array}$ \\
\hline
\end{tabular}




\section{References}

Agnello L., Castro V., Jalles J. T., and Sousa R. M., 2015, "What determines the likelihood of structural reforms?" European Journal of Political Economy 37, pp. 129 - 145.

Alfonso A., Kiss Á., Pálvölgyi B., and Turrini A., 2014, “Labour Mobility and Labour Market Adjustment in the EU," European Commission.

Allard C. and Everaert L., 2010, "Lifting Euro Area Growth: Priorities for Structural Reforms and Governance," International Monetary Fund, 2010.

Andrle M., Bluedorn J. C., Eyraud L., Kinda T., Koeva Brooks P., Schwartz G., and Weber A., 2015, "Reforming Fiscal Governance in the European Union," IMF Staff Discussion Notes 15/9, International Monetary Fund.

Anderson D., Barkbu B., Lusinyan L., and Muir D., 2014, “Assessing the Gains from Structural Reforms for Jobs and Growth," in "Jobs and Growth: Supporting the European Recovery," April 2014.

Barkbu B., Rahman J., Valdẻz R., and an IMF staff team, 2012, "Fostering Growth in Europe Now," IMF Staff Discussion Note, No. 12/07, June 2012.

Bassanini A. and Duval R., 2006, "Employment Patterns in OECD Countries: Reassessing the Role of Policies and Institutions," DELSA/ELSA/WD/SEM(20064).

Berger H. and Danninger S., 2006, "The Employment Effects of Labor and Product Markets Deregulation and their Implications for Structural Reforms," CESIFO Working Paper 1709.

Bouis R. and Duval R., 2011, "Raising Potential Growth After the Crisis: A Quantitative Assessment of the Potential Gains from Various Structural Reforms in the OECD Area and Beyond", OECD Economics Department Working Papers, No. 835, OECD Publishing. http://dx.doi.org/10.1787/5kgk9qj18s8n-en.

Buti M., Röger W., and Turrini A., 2009, “Is Lisbon Far from Maastricht? Trade-offs and Complementarities between Fiscal Discipline and Structural Reforms," CESifo Economic Studies, Vol. 55, No. 3, pp. 165-96.

Buti M., Turrini A., and van den Noord P., 2014, "Reform and be Re-Elected: Evidence from the Post-Crisis Period," Vox, July 4 (London: Centre for Economic Policy Research).

Cœuré B., 2014, "Structural Reforms: Learning the Right Lessons from the Crisis," Keynote speech, Economic conference, Latvijas Banka, Riga, 17 October 2014.

Debrun X. and Kinda T., 2014, "Strengthening Post-Crisis Fiscal Credibility: Fiscal Councils on the Rise. A New Dataset," IMF Working Papers 14/58, International Monetary Fund. 
Deroose S., and Griesse D., 2014, "Implementing Economic Reforms - Are EU Member States Responding to European Semester recommendations?" ECFIN Economic Brief Issue 37.

Draghi M., 2014, "Stability and Prosperity in Monetary Union,” University of Helsinki, Helsinki, 27 November 2014.

European Central Bank, 2015, "Progress with Structural Reforms Across the Euro Area and Their Possible Impacts,” ECB Economic Bulletin, Issue 2, 2015.

European Commission, 2005, "Communication from the Commission on an EU common methodology for assessing administrative costs imposed by legislation", $\operatorname{COM}(2005)$ 518.

, 2014a, European Commission Communication on Economic Governance Review, COM(2014) 905, November 28, 2014. , 2014b, Single Market Scoreboard, Edition 07/2014. , 2014c, “Annual Growth Survey 2015”, Communication 2015 (902). , 2014d, "Economic Governance Review: Communication from the Commission to the European Parliament, the Council, the European Central Bank, the European Economic and Social Committee and the Committee of the Regions."

Hobza A. and Mourre G., 2010, "Quantifying the Potential Macroeconomic Effects of the Europe 2020 Strategy: Stylized Scenarios,” European Economy Economic Paper No. 424, (Brussels, European Commission).

Ioannou D., Ferdinandusse M., Lo Duca M., and Coussens W., 2008, "Benchmarking the Lisbon Strategy", ECB Occasional Paper Series 85.

Ioannou D. and Stracca, L., 2014, "Have the euro area and EU worked? Just the facts", European Journal of Political Economy 34, pp. 1-17.

International Monetary Fund, 2013, “Toward a Fiscal Union for the Euro Area,” Washington DC.

,2014a, "External Rebalancing in the Euro Area: Developments and Policies," IMF Country Report No. 14/199.

,2014b, “Back to Work How Fiscal Policy Can Help,” Fiscal Monitor, October 2014.

Juncker J., 2014, “A New Start for Europe: My Agenda for Jobs, Growth, Fairness and Democratic Change; Political Guidelines for the next European Commission, 2014. 
Juncker J., Draghi M., Dijsselbloem J., Schulz M., and Tusk D., 2015, “Completing Europe’s Economic and Monetary Union."

Leiner-Killinger N., Perez V. L., Stiegert R., and Vitale G., 2007, "Structural Reforms in EMU and the Role of Monetary Policy A Survey of the Literature”, ECB Occasional Paper 66.

Lora E., and Olivera M., 2004, "What Makes Reforms Likely: Political Economy Determinants of Reforms in Latin America”, Journal of Applied Economics, VII (I), pp. $99-135$.

Monteagudo J., Rutkowski A., and Lorenzani D., 2012, "The Economic Impact of the Services Directive: A First Assessment Following Implementation," European Commission Economic Papers 456.

OECD, 2008, "The GDP Impact of Structural Reforms: A Simulation Framework," Working Party No.1 on Macroeconomic and Structural Policy analysis, $\mathrm{ECO} / \mathrm{CPE} / \mathrm{WP} 1(2008) 6$.

OECD, 2014, "Structural Reforms: Impact on Growth and Options for the Future," OECD Publishing, Paris.

OECD, 2015, “Economic Policy Reforms 2015: Going for Growth,”, OECD Publishing, Paris. https://dx.doi.org/10.1787/growth-2015-en.

Padoan P. and Schäuble W., 2014, “A Pro-Growth, Pro-business Agenda for Europe,” Wall Street Journal.

Sapir A. and Wolff G., 2015, "Euro Area Governance: What to Reform and How to do it," Bruegel Policy Brief Issue 2015/01.

Padoa-Schioppa T. Group, 2012, Completing the Euro: a Roadmap Toward Fiscal Union in Europe, http://www.eng.notre-europe.eu/011-3317-Completing-the-EuroA-road-maptowards-fiscal-union-in-Europe.html, June 26, 2012.

Van Rompuy H., Barroso J., Juncker J., and Draghi M., 2012, “Towards a Genuine Economic and Monetary Union."

Varga J. and in 't Veld J., 2013, "The Growth Impact of Structural Reforms," European Commission DG ECFIN Quarterly Report on the euro area, Vol. 12, No. 4. 